\title{
Historical Changes in Annual Peak Flows in Maine and Implications for Flood-Frequency Analyses
}

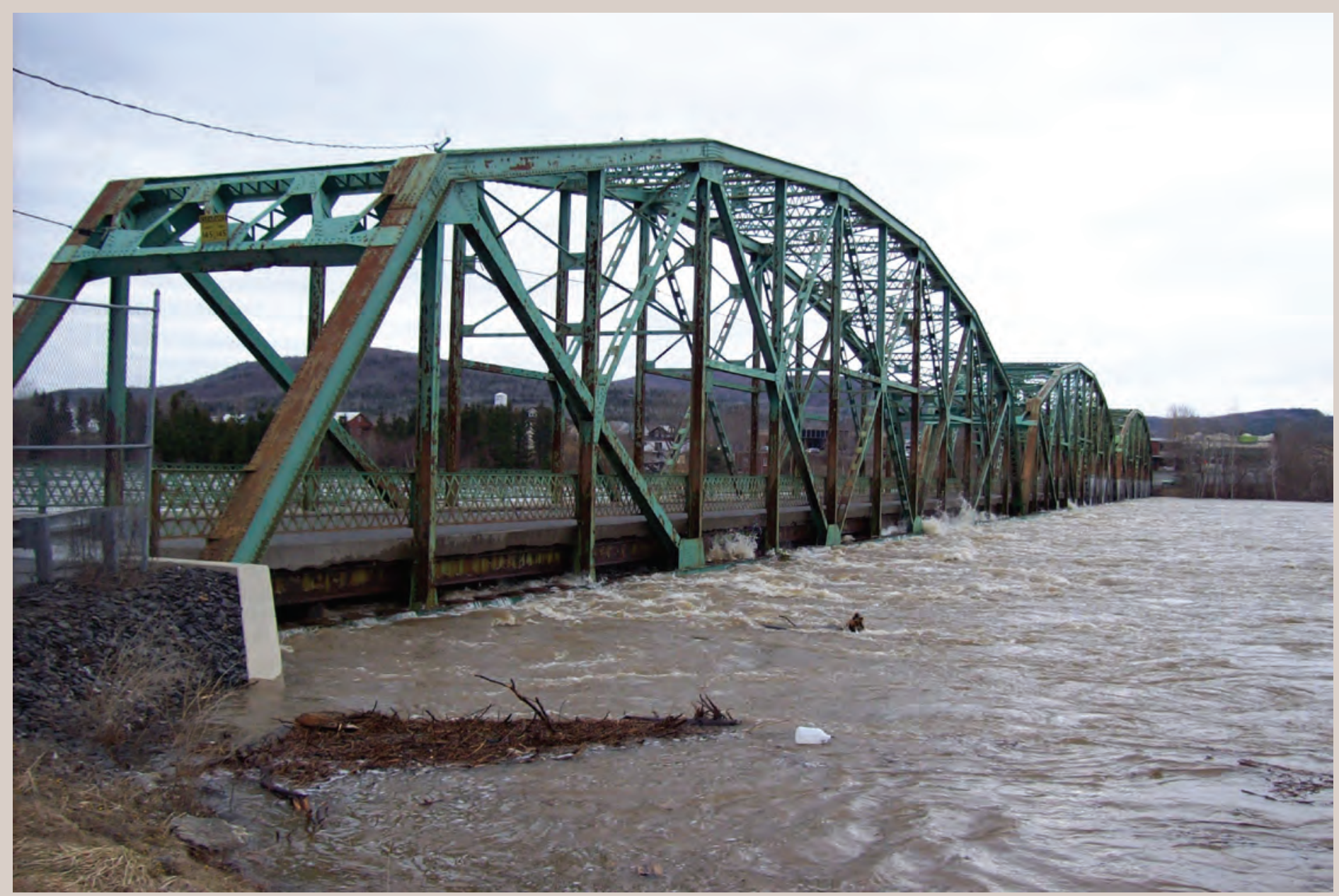

Scientific Investigations Report 2010-5094 
Cover. St. John River at Ft. Kent, Maine, April 29, 2009. Photo credit: Andrew Cloutier, USGS 


\section{Historical Changes in Annual Peak Flows in Maine and Implications for Flood- Frequency Analyses}

By Glenn A. Hodgkins

Prepared in cooperation with the Maine Department of Transportation

Scientific Investigations Report 2010-5094 


\title{
U.S. Department of the Interior \\ KEN SALAZAR, Secretary \\ U.S. Geological Survey \\ Marcia K. McNutt, Director
}

\section{U.S. Geological Survey, Reston, Virginia: 2010}

\author{
For more information on the USGS — the Federal source for science about the Earth, its natural and living resources, \\ natural hazards, and the environment, visit http://www.usgs.gov or call 1-888-ASK-USGS \\ For an overview of USGS information products, including maps, imagery, and publications, \\ visit http://www.usgs.gov/pubprod \\ To order this and other USGS information products, visit http://store.usgs.gov
}

\begin{abstract}
Any use of trade, product, or firm names is for descriptive purposes only and does not imply endorsement by the U.S. Government.

Although this report is in the public domain, permission must be secured from the individual copyright owners to reproduce any copyrighted materials contained within this report.
\end{abstract}

Suggested citation:

Hodgkins, G.A., 2010, Historical changes in annual peak flows in Maine and implications for flood-frequency analyses: U.S. Geological Survey Scientific Investigations Report 2010-5094, 38 p., at http://pubs.usgs.gov/sir/2010/5094. 


\section{Contents}

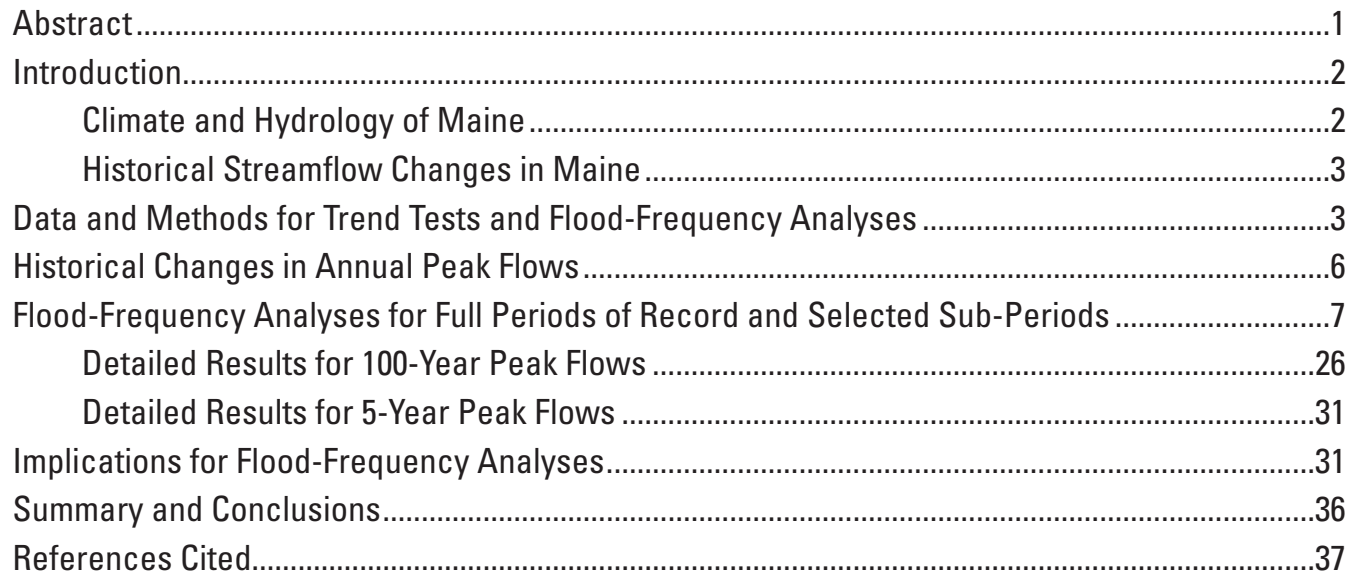

\section{Figures}

1. Graphs showing examples of annual peak flows and Sen slopes at A, St. John River, Ft. Kent, Maine and B, Little Androscoggin River, South Paris, Maine.....

2. Map showing geographic distribution of the magnitude of annual peak-flow linear changes over time as computed by use of the Sen slope. River and location for map numbers are in table 1.

3. Map showing geographic distribution of the magnitude of annual peak-flow step changes over time as computed by use of the Hodges-Lehmann estimator.

4. Graph showing distribution of differences for various rivers between 100-year peak flows based on selected sub-periods and 100 -year peak flows based on full periods of record

5. Graph showing distribution of differences for various rivers between 5-year peak flows based on selected sub-periods and 5-year peak flows based on full periods of record

6. Map showing geographic distribution of 100 -year peak flows based on the 1967 to 1996 sub-period that are outside the 90-percent confidence intervals of 100-year peak flows based on full periods

7. Map showing geographic distribution of 100 -year peak flows based on the 1937 to 1966 sub-period that are outside the 90-percent confidence intervals of 100-year peak flows based on full periods

8. Map showing geographic distribution of 100-year peak flows based on the 1971 to 2006 sub-period that are outside the 90-percent confidence intervals of 100-year peak flows based on full periods.

9. Map showing geographic distribution of 100-year peak flows based on the start-of-record to 1970 sub-period that are outside the 90-percent confidence intervals of 100-year peak flows based on full periods.

10. Map showing geographic distribution of 5-year peak flows based on the 1967 to 1996 sub-period that are outside the 90-percent confidence intervals of 5-year peak flows based on full periods 
11. Map showing geographic distribution of 5-year peak flows based on the 1937 to 1966 sub-period that are outside the 90-percent confidence intervals of 5-year peak flows based on full periods

12. Map showing geographic distribution of 5-year peak flows based on the 1971 to 2006 sub-period that are outside the 90-percent confidence intervals of 5-year peak flows based on full periods

13. Map showing geographic distribution of 5-year peak flows based on the start-of-record to 1970 sub-period that are outside the 90-percent confidence intervals of 5 -year peak flows based on full periods.

\section{Tables}

1. Peak flows for 5- and 100-year recurrence intervals computed from the full period of record for 28 selected streamgages in or near Maine

2. Magnitude of linear changes over time for annual peak flows as computed by use of the Sen slope.....

3. Magnitude of step changes over time in annual peak flows as computed by use of the Hodges-Lehmann estimator

4. Peak flows with 100-year recurrence intervals based on multiple 30-year sub-periods, and comparisons to 100 -year peak flows based on full periods.

5. Peak flows with 100 -year recurrence intervals based on the sub-periods 1971 to 2006 and start-of-record to 1970, and comparisons to 100-year peak flows based on full periods

6. Peak flows with 5-year recurrence intervals based on multiple 30-year sub-periods, and comparisons to 5-year peak flows based on full periods.

7. Peak flows with 5 -year recurrence intervals based on the sub-periods 1971 to 2006 and start-of-record to 1970, and comparisons to 5-year peak flows based on full periods

8. Median differences between peak flows for selected recurrence intervals based on sub-periods and peak flows based on full periods of record

9. Number of streamgages with 100 -year peak flows based on sub-periods that are outside of 90-percent confidence intervals of 100-year peak flows based on full periods of record

10. Number of streamgages with 5-year peak flows based on sub-periods that are outside of 90-percent confidence intervals of 5-year peak flows based on full records. 


\section{Conversion Factors and Datum}

\begin{tabular}{lcl}
\hline \multicolumn{1}{c}{ Multiply } & By & \multicolumn{1}{c}{ To obtain } \\
\hline inch (in.) & Length & centimeter $(\mathrm{cm})$ \\
inch (in.) & 2.54 & millimeter $(\mathrm{mm})$ \\
foot (ft) & 25.4 & meter $(\mathrm{m})$ \\
mile $(\mathrm{mi})$ & 0.3048 & kilometer $(\mathrm{km})$ \\
\hline & 1.609 & \\
\hline square foot $\left(\mathrm{ft}^{2}\right)$ & Area & square centimeter $\left(\mathrm{cm}^{2}\right)$ \\
square foot $\left(\mathrm{ft}^{2}\right)$ & 929.0 & square meter $\left(\mathrm{m}^{2}\right)$ \\
square inch $\left(\mathrm{in}^{2}\right)$ & 0.09290 & square centimeter $\left(\mathrm{cm}^{2}\right)$ \\
square mile $\left(\mathrm{mi}^{2}\right)$ & 6.452 & hectare $(\mathrm{ha})$ \\
square mile $\left(\mathrm{mi}^{2}\right)$ & 259.0 & square $\mathrm{kilometer}\left(\mathrm{km}^{2}\right)$ \\
\hline & 2.590 & \\
\hline cubic foot $\left(\mathrm{ft}^{3}\right)$ & Volume & cubic decimeter $\left(\mathrm{dm}^{3}\right)$ \\
cubic foot $\left(\mathrm{ft}^{3}\right)$ & 28.32 & cubic meter $\left(\mathrm{m}^{3}\right)$ \\
\hline & 0.02832 & meter per second $\left(\mathrm{m}^{3} / \mathrm{s}\right)$ \\
\hline $\begin{array}{l}\text { foot per second }(\mathrm{ft} / \mathrm{s}) \\
\text { cubic foot per second }(\mathrm{ft} 3 / \mathrm{s})\end{array}$ & Flow rate & cubic meter per second $\left(\mathrm{m}^{3} / \mathrm{s}\right)$ \\
cubic foot per second per square $\left[\left(\mathrm{ft}^{3} / \mathrm{s}\right) / \mathrm{mi}^{2}\right]$ & 0.3048 & square $\mathrm{kilometer}\left[\left(\mathrm{m}^{3} / \mathrm{s}\right) / \mathrm{km}^{2}\right]$ \\
\hline
\end{tabular}

Temperature in degrees Celsius $\left({ }^{\circ} \mathrm{C}\right)$ may be converted to degrees Fahrenheit $\left({ }^{\circ} \mathrm{F}\right)$ as follows:

$$
{ }^{\circ} \mathrm{F}=\left(1.8 x^{\circ} \mathrm{C}\right)+32
$$

Temperature in degrees Fahrenheit $\left({ }^{\circ} \mathrm{F}\right)$ may be converted to degrees Celsius $\left({ }^{\circ} \mathrm{C}\right)$ as follows:

$$
{ }^{\circ} \mathrm{C}=\left({ }^{\circ} \mathrm{F}-32\right) / 1.8
$$

Vertical coordinate information is referenced to the North American Vertical Datum of 1988 (NAVD 88).

Horizontal coordinate information is referenced to the North American Datum of 1983 (NAD 83).

Elevation, as used in this report, refers to distance above the vertical datum.

\section{List of Acronyms}

$\begin{array}{ll}\text { HCDN } & \text { Hydro-Climatic Data Network } \\ \text { MaineDOT } & \text { Maine Department of Transportation } \\ \text { NAO } & \text { North Atlantic Oscillation } \\ \text { USGS } & \text { U.S. Geological Survey } \\ \text { VIC } & \text { variable infiltration capacity }\end{array}$


This page has been left blank intentionally. 


\title{
Historical Changes in Annual Peak Flows in Maine and Implications for Flood-Frequency Analyses
}

\author{
By Glenn A. Hodgkins
}

\section{Abstract}

Flood-frequency analyses use statistical methods to compute peak streamflows for selected recurrence intervalsthe average number of years between peak flows that are equal to or greater than a specified peak flow. Analyses are based on annual peak flows at a stream. It has long been assumed that the annual peak streamflows used in these computations were stationary (non-changing) over very long periods of time, except in river basins subject to direct effects of human activities, such as urbanization and regulation. Because of the potential effects of global warming on peak flows, the assumption of peak-flow stationarity has recently been questioned. Maine has many streamgages with 50 to 105 years of recorded annual peak streamflows. In this study, this long-term record has been tested for historical floodfrequency stationarity, to provide some insight into future flood frequency.

Changes over time in annual instantaneous peak streamflows at 28 U.S. Geological Survey streamgages with long-term data (50 or more years) and relatively complete records were investigated by examining linear trends for each streamgage's period of record. None of the 28 streamgages had more than 5 years of missing data. Eight streamgages have substantial streamflow regulation. Because previous studies have suggested that changes over time may have occurred as a step change around 1970, step changes between each streamgage's older record (start year to 1970) and newer record (1971 to 2006) also were computed. The median change over time for all 28 streamgages is an increase of 15.9 percent based on a linear change and an increase of 12.4 percent based on a step change. The median change for the 20 unregulated streamgages is slightly higher than for all 28 streamgages; it is 18.4 percent based on a linear change and 15.0 percent based on a step change.

Peak flows with 100- and 5-year recurrence intervals were computed for the 28 streamgages using the full annual peak-flow record and multiple sub-periods of that record using the guidelines (Bulletin 17B) of the Interagency Advisory Committee on Water Data. Magnitudes of 100- and 5-year peak flows computed from sub-periods then were compared to those computed from the full period. Sub-periods of 30 years with starting years staggered by 10 years were evaluated
(1907-36, 1917-46, 1927-56, 1937-66, 1947-76, 1957-86, 1967-96, and 1977-2006). Two other sub-periods were evaluated using older data (start-of-record to 1970) and newer data (1971 to 2006). The 5-year peak flow is used to represent small and relatively frequent flood flows in Maine, whereas the 100-year peak flow is used to represent large flood flows.

The 1967-96 sub-period generated the highest 100 - and 5-year peak flows overall when compared to peak flows based on the full period of record; the median difference for all 28 streamgages is 8 percent for 100 - and 5 -year peak flows. The 1977-2006 and 1971-2006 sub-periods also generated 100- and 5-year peak flows higher than peak flows based on the full period of record, but not as high as the peak flows based on the 1967-96 sub-period. The 1937-66 sub-period generated the lowest 100- and 5-year peak flows overall. The median difference from full-period peak flows is -11 percent for 100 -year peak flows and -8 percent for 5 -year peak flows. Overall, differences between peak flows based on the sub-periods and those based on the full periods, generated using the 20 unregulated streamgages, are similar to differences using all 28 streamgages.

Increases in the 5- and 100-year peak flows based on recent years of record are, in general, modest when compared to peak flows based on complete periods of record. The highest peak flows are based on the 1967-96 sub-period rather than the most recent sub-period (1977-2006). Peak flows for selected recurrence intervals are sensitive to very high peak flows that may occur once in a century or even less frequently. It is difficult, therefore, to determine which approach will produce the most reliable future estimates of peak flows for selected recurrence intervals, using only recent years of record or the traditional method using the entire historical period. One possible conservative approach to computing peak flows of selected recurrence intervals would be to compute peak flows using recent annual peak flows and the entire period of record, then choose the higher computed value. Whether recent or entire periods of record are used to compute peak flows of selected recurrence intervals, the results of this study highlight the importance of using recent data in the computation of the peak flows. The use of older records alone could result in underestimation of peak flows, particularly peak flows with short recurrence intervals, such as the 5-year peak flows. 


\section{Introduction}

Flood-frequency analyses use statistical methods to compute peak streamflows for selected recurrence intervalsthe average number of years between peak flows that are equal to or greater than a specified peak flow. For example, the 100 -year peak flow is the flow that would be equaled or exceeded, on long-term average, once in 100 years. This does not imply, however, that flooding will happen at regular intervals. Two 100-year peak flows could occur within a few years of each other. In contrast, a 100-year peak flow might not occur in 200 years. The reciprocal of the recurrence interval is called the annual exceedance probability; that is, the probability that a given peak flow will be equaled or exceeded in any given year. For example, the annual exceedance probability of the 100 -year peak flow would be 0.01 . In other words, there is a 1 percent chance that the 100 -year peak flow will be equaled or exceeded in any given year.

Determination of the magnitude of peak streamflows with specified recurrence intervals is necessary to safely and economically design bridges, culverts, and other structures that are in, or near, streams. These peak flows are also needed by Federal, State, regional, and local officials for effective floodplain management.

It has been known for decades that peak flows of selected recurrence intervals computed from shorter periods of annual peak-flow record can differ substantially from those computed from longer periods of record (Benson, 1960). It has long been assumed, however, that annual peak streamflows are stationary over very long periods of time, except in river basins subject to urbanization, regulation, and other human activities.

Stationarity is the concept that natural systems fluctuate within an envelope of variability that does not change over time (Milly and others, 2008). Because of the potential effects of global warming on peak flows, the assumption of peak-flow stationarity has recently been questioned (Milly and others, 2008). In New England, Hayhoe and others (2007) used climate projections as input to the variable infiltration capacity (VIC) hydrologic model. On the basis of this modeling, spring streamflow timing is expected to become earlier during the next 90 years, and high streamflows (50th to 95th percentile annual flows) are expected to increase.

If peak flows increase in the next century due to global warming, peak flows of selected recurrence intervals may also increase. Because bridges and culverts in Maine were designed with the assumption of peak-flow stationarity, bridges could be under-designed for future large floods. Maine has many streamgages with 50 to 105 years of recorded annual peak streamflows. In this study, this long-term record has been tested for historical flood-frequency stationarity to provide some insight into future flood frequency. Collins (2009) computed peak flows for a range of recurrence intervals for seven streamgages in New England that showed the strongest evidence of upward peak-flow trends and step (abrupt) increases around 1970 (out of 28 streamgages tested for trends). The peak flows for selected recurrence intervals were based on the entire periods of recorded peak flows at the streamgages, pre-1970 peak flows, and post-1970 peak flows. A majority of streamgages had higher magnitudes of peak flows for all recurrence intervals for computations based on post-1970 annual peak flows as compared to those based on pre-1970 peak flows. All seven streamgages had higher magnitudes of peak flows for 1- to 10-year recurrence intervals for computations based on post-1970 peak flows as compared to those based on pre-1970 peak flows.

This report, prepared by the U.S. Geological Survey (USGS) in cooperation with the Maine Department of Transportation (MaineDOT), will help MaineDOT and others better understand the effects of changing historical peak flows on flood-frequency computations for streams in Maine. To accomplish this, changes over time in annual peakflow magnitudes were evaluated for 28 streamgages in and near Maine with long-term records. Then, 5- and 100-year recurrence interval peak flows were computed for these streamgages using the full available annual peak-flow record and multiple sub-periods of that record. The 5-year peak flow is used to represent small and relatively frequent flood flows in Maine, whereas the 100-year peak flow is used to represent large flood flows. Magnitudes of 5- and 100-year peak flows computed from sub-periods are then compared to peak flows based on the full period and are also compared to 90-percent confidence intervals of the peak flows based on the full period.

\section{Climate and Hydrology of Maine}

The climate of Maine is complex and variable across both space and time. Latitude, proximity to the Atlantic Coast, and variations in land-surface elevation have major effects on the climate (New England Regional Assessment Group, 2001). Maine is about halfway between the equator and the North Pole and is affected by warm, moist air from the south and cold, dry air from the north. The Atlantic Ocean moderates air temperatures in winter and summer, but the effects decrease with distance from the coast. In winter, the ocean variably affects the location of snow/rain boundaries. Despite the effects of the ocean, the prevailing air flow is not from the Atlantic Ocean, but from the drier North American continent. The mountainous topography of western and northwestern Maine affects precipitation and air temperatures. Precipitation is higher on the windward side of mountains and lower on the leeward side; however, storm-track directions through the mountains are highly variable so the windward and leeward areas differ for different storms. Air temperature decreases with higher elevation.

Maine generally has a temperate climate with mild summers and cold winters. From 1971 to 2000, the mean annual temperature statewide was about $42^{\circ} \mathrm{F}$, but it ranged from $36^{\circ} \mathrm{F}$ in northern Maine to $47^{\circ} \mathrm{F}$ in southern Maine (National Oceanic and Atmospheric Administration, 2002). During the same period, statewide mean monthly temperatures 
ranged from $15^{\circ} \mathrm{F}$ in January to $67^{\circ} \mathrm{F}$ in July. Precipitation in Maine is fairly evenly distributed throughout the year. The statewide mean annual precipitation for 1971 to 2000 was 43 in., ranging from 35 in. in northern Maine to 57 in. in eastern coastal Maine.

The snowpack in Maine typically accumulates throughout the winter and reaches its maximum depth and water equivalent (the depth of water that would result if the snowpack melted) in March or April. The median seasonal maximum depth of the snowpack for 1955 to 1992 varied from about $20 \mathrm{in}$. along the coast to more than $32 \mathrm{in}$. in the western mountains and in northern Maine (Cember and Wilks, 1993). The average water equivalent on or near March 1 ranged from 3 to $5 \mathrm{in}$. along the coast to 7 to $9 \mathrm{in}$. at the western mountains and in northern Maine (Loiselle and Hodgkins, 2002). The 109 snowpack data collection sites evaluated by Loiselle and Hodgkins (2002) had an average of 43 years of record through 2000. Almost all of the data-collection sites were lower than $2,000 \mathrm{ft}$ in elevation and, therefore, do not represent the full range of average water equivalent in Maine, as many mountains have substantial areas higher than 2,000 ft.

Streamflows in Maine typically are highest in the spring, when rain falls on a ripe (dense, ready to melt) snowpack or on saturated soils. Streamflows recede as snowmelt ends and as evapotranspiration increases. This recession is frequently interrupted by runoff from rainstorms. Warm-season streamflows are usually lowest in August and September. In the fall, after evapotranspiration decreases substantially, repeated rains often saturate the soil, leading to high streamflows. Also in the fall, large amounts of rain can fall as a result of hurricanes, tropical storms, or their remnants. Winter streamflows are generally low in northern areas of Maine where winter precipitation typically falls as snow. Winter streamflows in southern areas of Maine can be more variable than streamflows in the northern areas because of more winter rain.

\section{Historical Streamflow Changes in Maine}

A series of recent investigations by the U.S. Geological Survey has documented changes in several components of the water cycle, including streamflows, in Maine during the last 30 to 40 years. These changes are summarized in Hodgkins and others (2009). Winter-spring streamflows became earlier in northern and mountainous sections of Maine during the 20th century, with most of the 1- to 2-week change occurring in the last 30 years (Dudley and Hodgkins, 2002; Hodgkins and others, 2003; Hodgkins and Dudley, 2006). Winter-spring streamflow timing is based on the center-of-volume datethe date each year that half of the winter-spring streamflow volume passes a streamgage. Annual peak flows have increased significantly $(\mathrm{p}<0.1)$ during the last 50 to 100 years at about one-third of streamgages in Maine (Hodgkins and Dudley, 2005; Collins, 2009); no streamgages had significantly decreasing peak flows. Historical peak-flow changes may have occurred in a step change around 1970 (Collins, 2009), as has been observed at streamgages in Maine for changes in winterspring streamflow timing (Hodgkins and Dudley, 2006).

Weak, yet in some cases statistically significant, correlations have been found between various historical streamflows in New England and measures of the North Atlantic Oscillation (NAO) (Collins, 2009). The NAO refers to a redistribution of atmospheric mass between the Arctic and the subtropical Atlantic. It swings from one phase to another to produce large changes in wind speed and direction over the Atlantic, heat and moisture transport between the Atlantic and neighboring continents, and the intensity and number of storms (Hurrell and others, 2003). The NAO tended to stay in a strong negative phase in the 1960s and stay in a strong positive phase in the 1990s.

\section{Data and Methods for Trend Tests and Flood-Frequency Analyses}

The USGS has been collecting and publishing streamflow data for streamgages in and near Maine since 1901. The data are available online at http://waterdata.usgs.gov/me/nwis/ sw. Streamgage data were examined to locate streamgages, both regulated and unregulated, with at least 50 years of annual peak-flow data up to the present (2006) and with no more than 5 years of missing data from 1957 through 2006. Regulated streamgages were included to increase the number of streamgages in the study, particularly streamgages with 90 or more years of record. Twenty-eight streamgages met the above criteria (table 1); annual instantaneous peak flows at these streamgages were used for all analyses in this report. Peak flows for 5- and 100-year recurrence intervals at the streamgages computed from full periods of record are listed in table 1, thus showing the magnitudes of small and large floods on various streams and rivers in and near Maine during the last century.

Eight of 28 streamgages that met minimum data requirements are considered to be substantially regulated (table 1) in terms of the effect of reservoir regulation on peak streamflows. Benson (1962) determined that usable reservoir storage of less than 4.5 million cubic feet per square mile would, in general, affect peak flows by less than 10 percent. The eight substantially regulated streamgages in this study have reservoir storage that exceeds this amount.

Most of the remaining 20 unregulated streamgages are part of the USGS Hydro-Climatic Data Network (HCDN), which includes data from 1,659 streamgages across the United States (Slack and Landwehr, 1992). This network includes streamgages with data from basins lacking overt effects of human activities, such as regulation, diversion, land-use change, or extreme groundwater withdrawals. The HCDN was developed for the purpose of studying the variation in streamflow over time that results from climatic variation. Three of 20 streamgages (streamgages 7, 17, and 28 in table 1) 
Table 1. Peak flows for 5 - and 100-year recurrence intervals computed from the full period of record for 28 selected streamgages in or near Maine.

[USGS, U.S. Geological Survey; mi², square miles; $\mathrm{ft}^{2}$ /s, cubic feet per second; NB, New Brunswick; NH, New Hampshire; R, regulated]

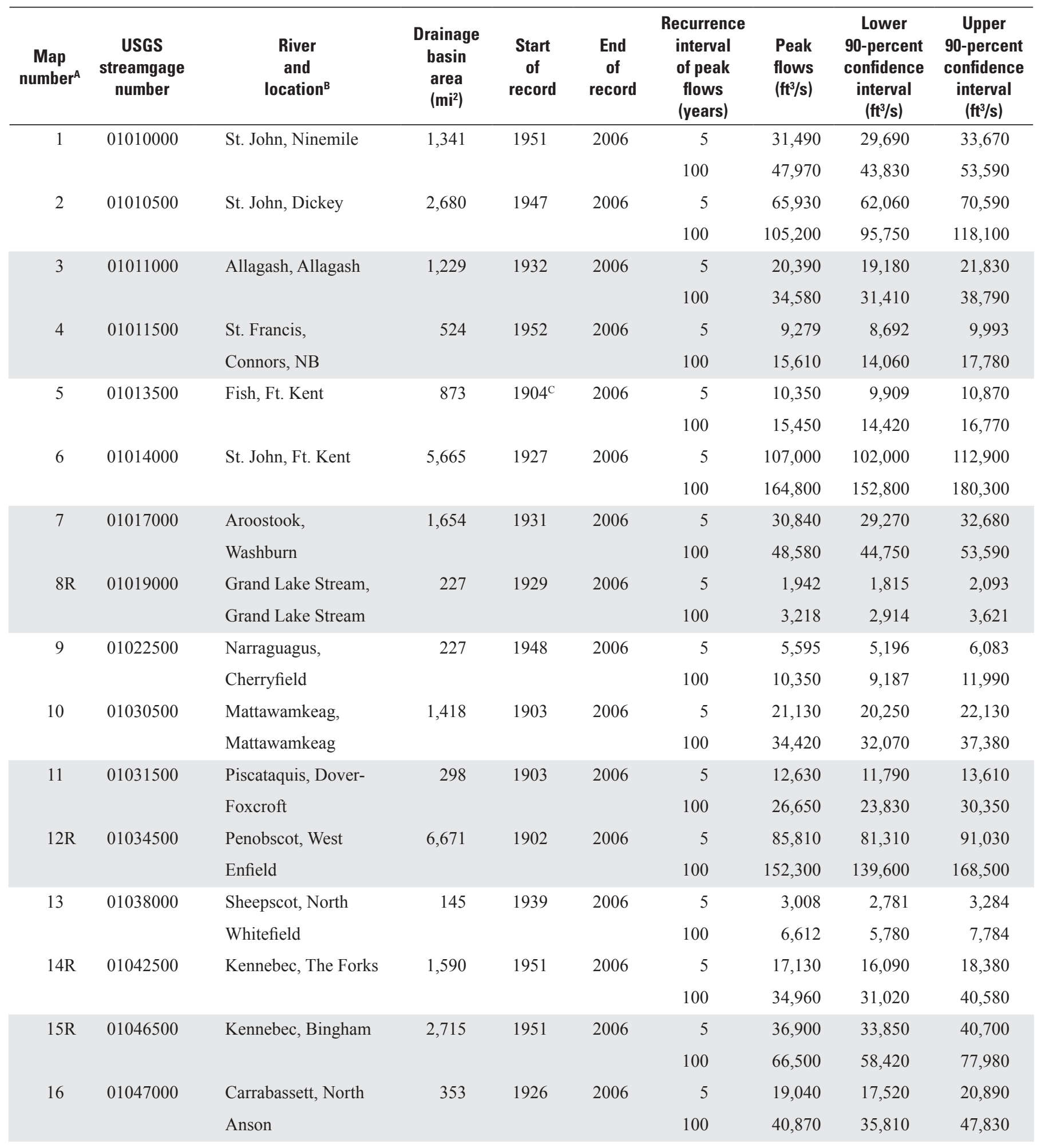


Table 1. Peak flows for 5 - and 100 -year recurrence intervals computed from the full period of record for 28 selected streamgages in or near Maine.

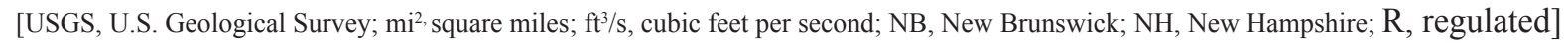

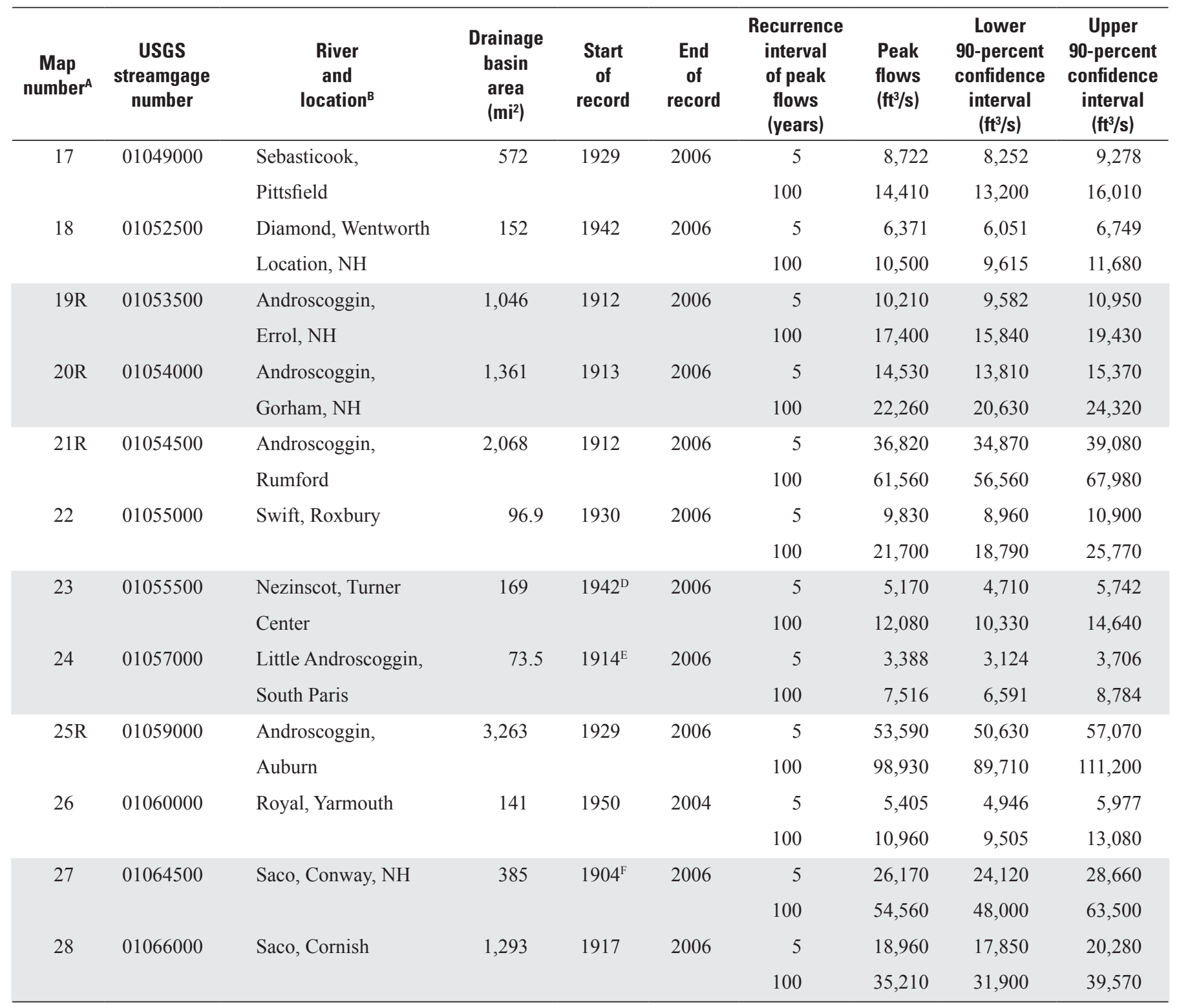

A " $R$ " beside a number indicates regulated streamgage (streamgage has drainage basin with more than 4.5 million cubic feet of usable storage per mile (Benson, 1962)).

${ }^{\text {B }}$ All locations in Maine unless noted.

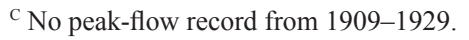

${ }^{\mathrm{D}}$ No peak-flow record from 1997-2001.

E No peak-flow record from 1924-1931.

${ }^{\mathrm{F}}$ No peak-flow record from 1910-1929. 
Historical Changes in Annual Peak Flows in Maine and Implications for Flood-Frequency Analyses

without substantial peak-flow regulation, as defined by Benson (1962), are not included in the HCDN network because they have regulation that is expected to substantially affect monthly mean flows.

The magnitudes of annual peak-flow changes over time were computed using the Sen slope (also known as the Kendall-Theil robust line). This slope is computed as the median of all possible pairwise slopes in each temporal data set (Helsel and Hirsch, 1992). The slope was multiplied by the appropriate number of years of data to obtain changes over time for the period of record. Peak-flow step changes between old data (start-of-record to 1970) and new data (1971-2006) at streamgages were computed using the Hodges-Lehmann estimator, the median of all pairwise changes between two groups of data (Helsel and Hirsch, 1992). These methods are more robust to outliers than linear regression or the computation of the mean difference between two groups.

The significance of peak-flow changes over time is not reported for this study. The magnitude and direction of hydroclimatological trends over time can be determined with little ambiguity; however, the concept of statistical significance is meaningless when discussing systems with poorly understood serial structure (Cohn and Lins, 2005; Koutsoyiannis and Montanari, 2007). Trend tests that fail to consider long-term persistence in the data (such as the MannKendall test) greatly overstate the statistical significance of observed trends when long-term persistence is present (Cohn and Lins, 2005; Khaliq and others, 2009).

The 5- and 100-year peak flows for full periods of record and sub-periods at streamgages were computed using the guidelines (Bulletin 17B) of the Interagency Advisory Committee on Water Data (1982). The computations involved fitting the Pearson Type III probability distribution to the logarithms (base 10) of the observed annual peak flows at a streamgage. This required computation of the mean, the standard deviation, and the skew of the logarithms of the annual peak-flow data. Peak flows for selected recurrence intervals were determined from the fitted curve.

There are several streamgages on regulated streams in Maine where substantial regulation was added (sometimes in addition to substantial regulation already in place) during the period for which annual peak flows are available. The older, less regulated annual peak flows were not used in the analyses based on the Bulletin 17B guidelines if regulation in the drainage basin, at the time of the older peaks, differed by more than approximately 4.5 million cubic feet of usable storage per square mile (Benson, 1962) from the regulation at the time of newer peaks. For example, the creation of Aziscohos Lake in 1911 resulted in a major change in reservoir storage, affecting the Androscoggin River; therefore, recorded peak flows prior to 1912 were not used. In addition, older peaks in Maine were not used if the annual peak-flow data at a streamgage clearly indicated that the regulation of peak flows had changed substantially over time.

Bulletin 17B guidelines were followed for the treatment of high and low outliers, for the conditional probability adjustment, and for weighting the streamgage skew coefficient with a generalized skew coefficient. In some cases, multiple low outliers that were near, but not below, the Bulletin 17B low outlier threshold were censored (dropped from the data set) if doing so improved the fit between the logs of the observed annual peaks and the Pearson Type III distribution. All high outliers were retained in the analyses. Historical information (information on peak flows outside the period of systematic data collection) was not used for this study. The historical information would not have been known for some of the sub-periods of continuous records that were used in this study, and for consistency historical information was not used for any of the full periods or sub-periods. The streamgage skews for the flood-frequency analyses were not weighted with the generalized skew if the annual peak flows at a streamgage were substantially affected by regulation. A streamgage was considered substantially regulated if its drainage basin had more than 4.5 million cubic feet of usable storage per mile (Benson, 1962). The generalized skew coefficient developed for Maine by Hodgkins (1999) was used for the current study. This skew coefficient is 0.029 , with a mean square error of prediction of 0.088 (or a standard error of prediction of 0.297 ). This generalized skew was the most accurate of four tested methods of estimating the generalized skew coefficient. Average streamgage skews for the current study from all available streamgages without substantial regulation from older sub-periods (1937-66 and 1947-76) did not differ substantially from average streamgage skews from more recent sub-periods (1967-96 and 1977-2006); average streamgage skews were $-0.01,0.03,-0.05$, and -0.04 , respectively. The annual peak flows at the streamgages in this study did not show obvious evidence that they were caused by multiple generating mechanisms. The procedures used to handle such a situation, therefore, were not used. Expected probability adjustments, which are explained in Bulletin 17B, were not made.

Peak flows for 5- and 100-year recurrence intervals at individual streamgages, computed as described above, were not combined with peak flows from regional regression equations for an individual streamgage. Peak flows for selected recurrence intervals at individual unregulated streamgages typically are combined with regional regressionequation peak flows to improve the peak-flow computations. For this report, however, the main interest is in the relative differences in peak flows for selected recurrence intervals that were computed using different periods of historical peak flows.

\section{Historical Changes in Annual Peak Flows}

Changes over time in annual instantaneous peak streamflows at 28 USGS streamgages with long-term data (50 or more years) and relatively complete records (no more 
than 5 years of missing data from 1957 through 2006) were investigated in two different ways. Linear trends for the period of record at each streamgage were computed using the Sen slope (see "Data and Methods for Trend Tests and Flood-frequency Analyses" section for more details). Because changes over time may have occurred as a step change around 1970 (see "Historical Streamflow Changes in Maine" section), step changes between each streamgage's older record (from starting year to 1970) and newer record (1971 to 2006) were computed using the Hodges-Lehmann estimator. Examples of annual peak flows and Sen slopes are shown in figure 1 for two streamgages that had typical changes over time, St. John River (streamgage 6) and Little Androscoggin River (streamgage 24).

The Sen slopes for the 28 streamgages varied considerably, but 22 of the streamgages have positive slopes, indicating increasing annual peak flows over time (table 2, fig. 2). There is no obvious geographic pattern to the slopes (fig. 2). At many streamgages, increases are greater than 10 percent, and at seven streamgages, increases are greater than 25 percent. In contrast, at one streamgage peak flows decreased more than 10 percent. Results for streamgages with substantial streamflow regulation (table 2) do not show a markedly different pattern (fig. 2) than those for the unregulated streamgages.

Step changes for the 28 streamgages also varied considerably, but at 23 streamgages, peak flows increased after 1970 (table 3, fig. 3). Twenty-two of these 23 streamgages have positive linear slopes, as computed by use of the Sen slope. As with the linear trends, no geographic patterns for the step changes were obvious, and many increased annual peak flows of greater than 10 percent were noted when older data (1970 and earlier) were compared to newer data (1971 to 2006). At three streamgages, increases were greater than 25 percent, and at one streamgage, peak flows decreased more than 10 percent. Regulated streamgages (table 3 ) do not show a substantially different pattern of results (fig. 3) than those for the unregulated streamgages.

The median change over time for all 28 streamgages is an increase of 15.9 percent based on a linear change and 12.4 percent based on a step change. The median change for the 20 unregulated streamgages is slightly higher than for all 28 streamgages; it is 18.4 percent based on a linear change and 15.0 percent based on a step change. The median record length is 77.0 years for all 28 streamgages and 75.5 years for the unregulated streamgages.

\section{Flood-Frequency Analyses for Full Periods of Record and Selected Sub-Periods}

Peak flows with 100- and 5-year recurrence intervals were computed for all 28 streamgages using the full available

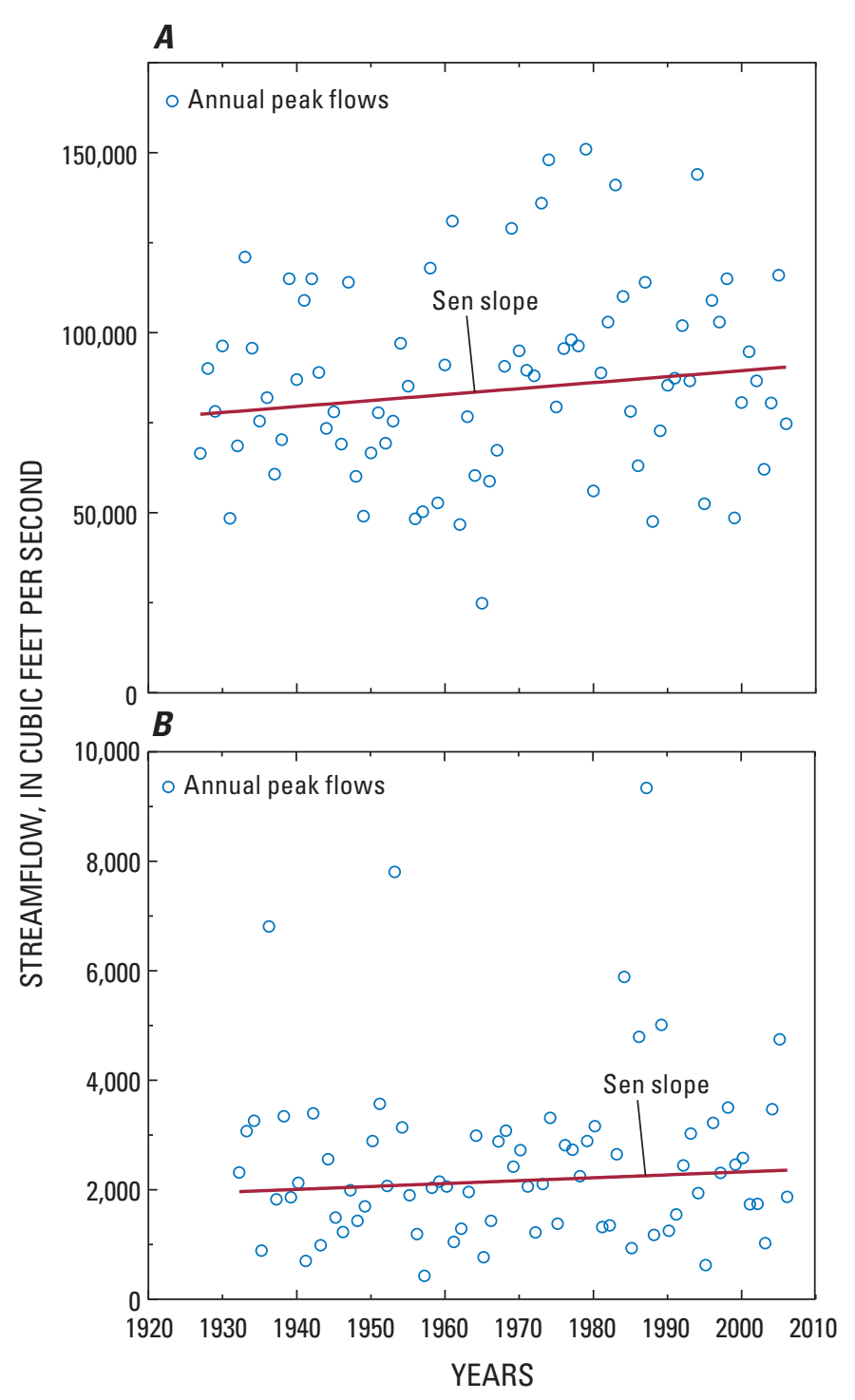

Figure 1. Examples of annual peak flows and Sen slopes at $A$, St. John River, Ft. Kent, Maine and $B$, Little Androscoggin River, South Paris, Maine.

annual peak-flow record (table 1) and multiple sub-periods of that record (tables 4-7). Magnitudes of 100- and 5-year peak flows computed from sub-periods were then compared to those from the full period and to the 90-percent confidence intervals of the peak flows computed from the full period (tables 4-7). Thirty-year sub-periods with starting years staggered by 10 years were used (1907-36, 1917-46, 1927-56, 1937-66, 1947-76, 1957-86, 1967-96, and 1977-2006). The number of sub-periods used depended on the length of record at each streamgage. Because a change in peak flows over time may have occurred as a step change around 1970 (see "Historical Streamflow Changes in Maine" section), two other sub-periods were analyzed: older data (start-of-record to 1970) and newer data (1971 to 2006). All results related to 100- and 5-year peak flows are summarized in tables 8, 9, and 10 . 
Table 2. Magnitude of linear changes over time for annual peak flows as computed by use of the Sen slope.

[USGS, U.S. Geological Survey; R, regulated]

\begin{tabular}{|c|c|c|c|c|}
\hline $\begin{array}{c}\text { Map } \\
\text { number }\end{array}$ & $\begin{array}{c}\text { USGS } \\
\text { streamgage } \\
\text { number }\end{array}$ & $\begin{array}{c}\text { Years of } \\
\text { record }\end{array}$ & $\begin{array}{l}\text { Magnitude } \\
\text { of change } \\
\text { (percent) }\end{array}$ & Regulation ${ }^{A}$ \\
\hline 1 & 01010000 & 56 & 28.6 & \\
\hline 2 & 01010500 & 60 & 28.7 & \\
\hline 3 & 01011000 & 75 & 12.6 & \\
\hline 4 & 01011500 & 55 & -4.0 & \\
\hline 5 & 01013500 & 77 & 4.8 & \\
\hline 6 & 01014000 & 80 & 17.0 & \\
\hline 7 & 01017000 & 76 & 13.9 & \\
\hline 8 & 01019000 & 78 & -5.1 & $\mathrm{R}$ \\
\hline 9 & 01022500 & 59 & -24.0 & \\
\hline 10 & 01030500 & 104 & 0.0 & \\
\hline 11 & 01031500 & 104 & 40.3 & \\
\hline 12 & 01034500 & 105 & 17.9 & $\mathrm{R}$ \\
\hline 13 & 01038000 & 68 & 22.8 & \\
\hline 14 & 01042500 & 56 & 4.9 & $\mathrm{R}$ \\
\hline 15 & 01046500 & 56 & 3.3 & $\mathrm{R}$ \\
\hline 16 & 01047000 & 81 & 23.2 & \\
\hline 17 & 01049000 & 78 & -2.3 & \\
\hline 18 & 01052500 & 65 & 30.9 & \\
\hline 19 & 01053500 & 95 & -1.2 & $\mathrm{R}$ \\
\hline 20 & 01054000 & 94 & 14.7 & $\mathrm{R}$ \\
\hline 21 & 01054500 & 95 & 31.2 & $\mathrm{R}$ \\
\hline 22 & 01055000 & 77 & 45.7 & \\
\hline 23 & 01055500 & 60 & 24.7 & \\
\hline 24 & 01057000 & 75 & 19.9 & \\
\hline 25 & 01059000 & 78 & 20.8 & $\mathrm{R}$ \\
\hline 26 & 01060000 & 55 & 0.8 & \\
\hline 27 & 01064500 & 77 & 63.4 & \\
\hline 28 & 01066000 & 90 & 5.2 & \\
\hline
\end{tabular}

${ }^{\mathrm{A}}$ Unregulated unless noted (streamgage has drainage basin with less than 4.5 million cubic feet of usable storage per mile (Benson, 1962)). 


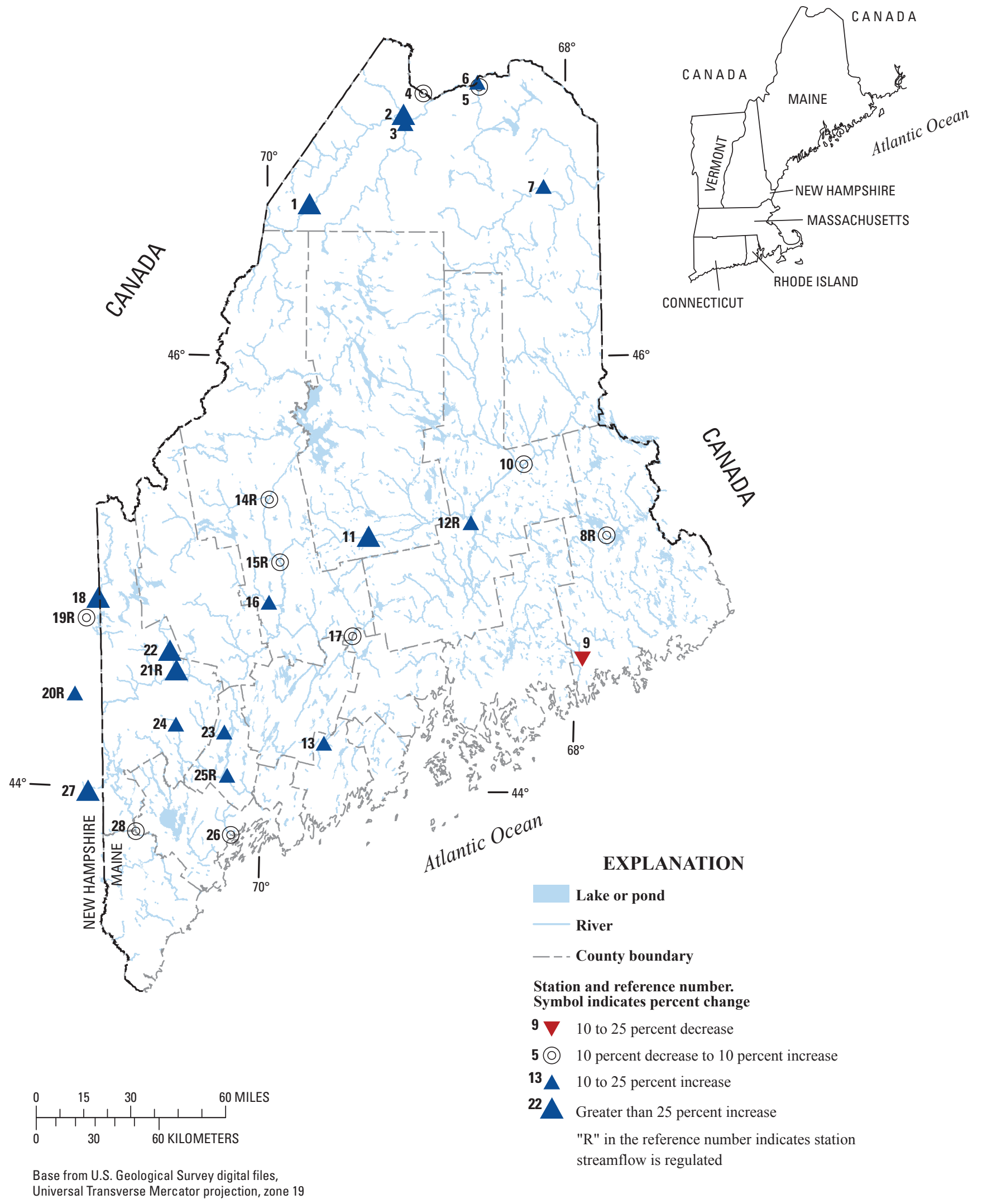

Figure 2. Geographic distribution of the magnitude of annual peak-flow linear changes over time as computed by use of the Sen slope. River and location for map numbers are in table 1. 
Table 3. Magnitude of step changes over time in annual peak flows as computed by use of the Hodges-Lehmann estimator.

[USGS, U.S. Geological Survey; R, regulated]

\begin{tabular}{|c|c|c|c|c|}
\hline $\begin{array}{c}\text { Map } \\
\text { number }\end{array}$ & $\begin{array}{c}\text { USGS } \\
\text { streamgage } \\
\text { number }\end{array}$ & $\begin{array}{l}\text { Years of } \\
\text { record }\end{array}$ & $\begin{array}{l}\text { Magnitude } \\
\text { of change } \\
\text { (percent) }\end{array}$ & Regulation ${ }^{A}$ \\
\hline 1 & 01010000 & 56 & 23.5 & \\
\hline 2 & 01010500 & 60 & 28.1 & \\
\hline 3 & 01011000 & 75 & 18.9 & \\
\hline 4 & 01011500 & 55 & 11.0 & \\
\hline 5 & 01013500 & 77 & 8.0 & \\
\hline 6 & 01014000 & 80 & 17.7 & \\
\hline 7 & 01017000 & 76 & 15.8 & \\
\hline 8 & 01019000 & 78 & -4.2 & $\mathrm{R}$ \\
\hline 9 & 01022500 & 59 & -10.4 & \\
\hline 10 & 01030500 & 104 & 4.7 & \\
\hline 11 & 01031500 & 104 & 26.5 & \\
\hline 12 & 01034500 & 105 & 15.0 & $\mathrm{R}$ \\
\hline 13 & 01038000 & 68 & 21.1 & \\
\hline 14 & 01042500 & 56 & 4.9 & $\mathrm{R}$ \\
\hline 15 & 01046500 & 56 & -0.6 & $\mathrm{R}$ \\
\hline 16 & 01047000 & 81 & 15.6 & \\
\hline 17 & 01049000 & 78 & -2.5 & \\
\hline 18 & 01052500 & 65 & 11.5 & \\
\hline 19 & 01053500 & 95 & -0.9 & $\mathrm{R}$ \\
\hline 20 & 01054000 & 94 & 7.6 & $\mathrm{R}$ \\
\hline 21 & 01054500 & 95 & 17.2 & $\mathrm{R}$ \\
\hline 22 & 01055000 & 77 & 19.3 & \\
\hline 23 & 01055500 & 60 & 11.8 & \\
\hline 24 & 01057000 & 75 & 11.7 & \\
\hline 25 & 01059000 & 78 & 13.1 & $\mathrm{R}$ \\
\hline 26 & 01060000 & 55 & 14.3 & \\
\hline 27 & 01064500 & 77 & 34.4 & \\
\hline 28 & 01066000 & 90 & 9.2 & \\
\hline
\end{tabular}

${ }^{\mathrm{A}}$ Unregulated unless noted (streamgage has drainage basin with less than 4.5 million cubic feet of usable storage per mile (Benson, 1962)). 


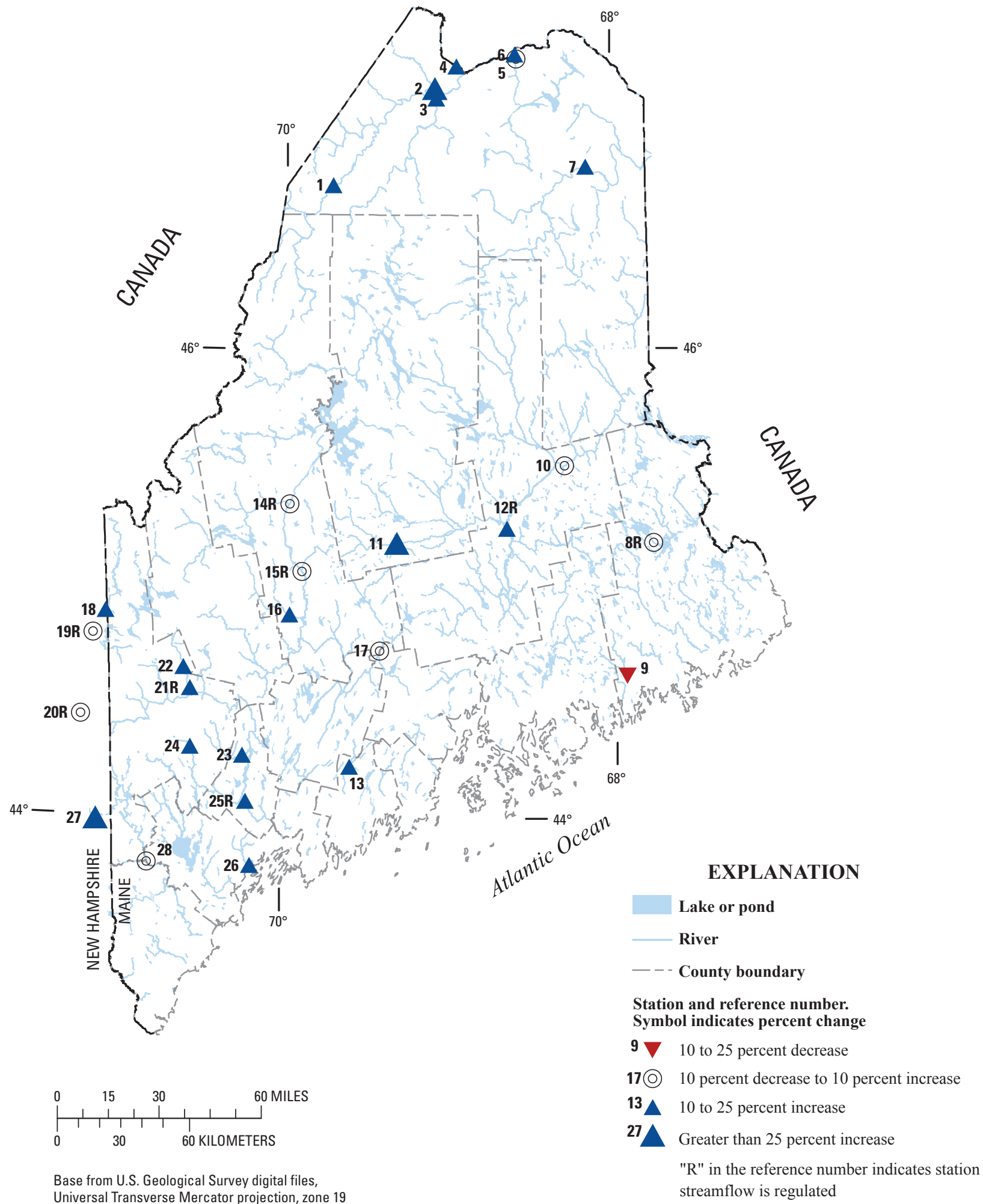

Figure 3. Geographic distribution of the magnitude of annual peak-flow step changes over time as computed by use of the Hodges-Lehmann estimator. 


\section{Historical Changes in Annual Peak Flows in Maine and Implications for Flood-Frequency Analyses}

Table 4. Peak flows with 100-year recurrence intervals based on multiple 30-year sub-periods, and comparisons to 100-year peak flows based on full periods.

[USGS, U.S. Geological Survey; $\mathrm{ft}^{3} / \mathrm{s}$, cubic feet per second; \%, percent]

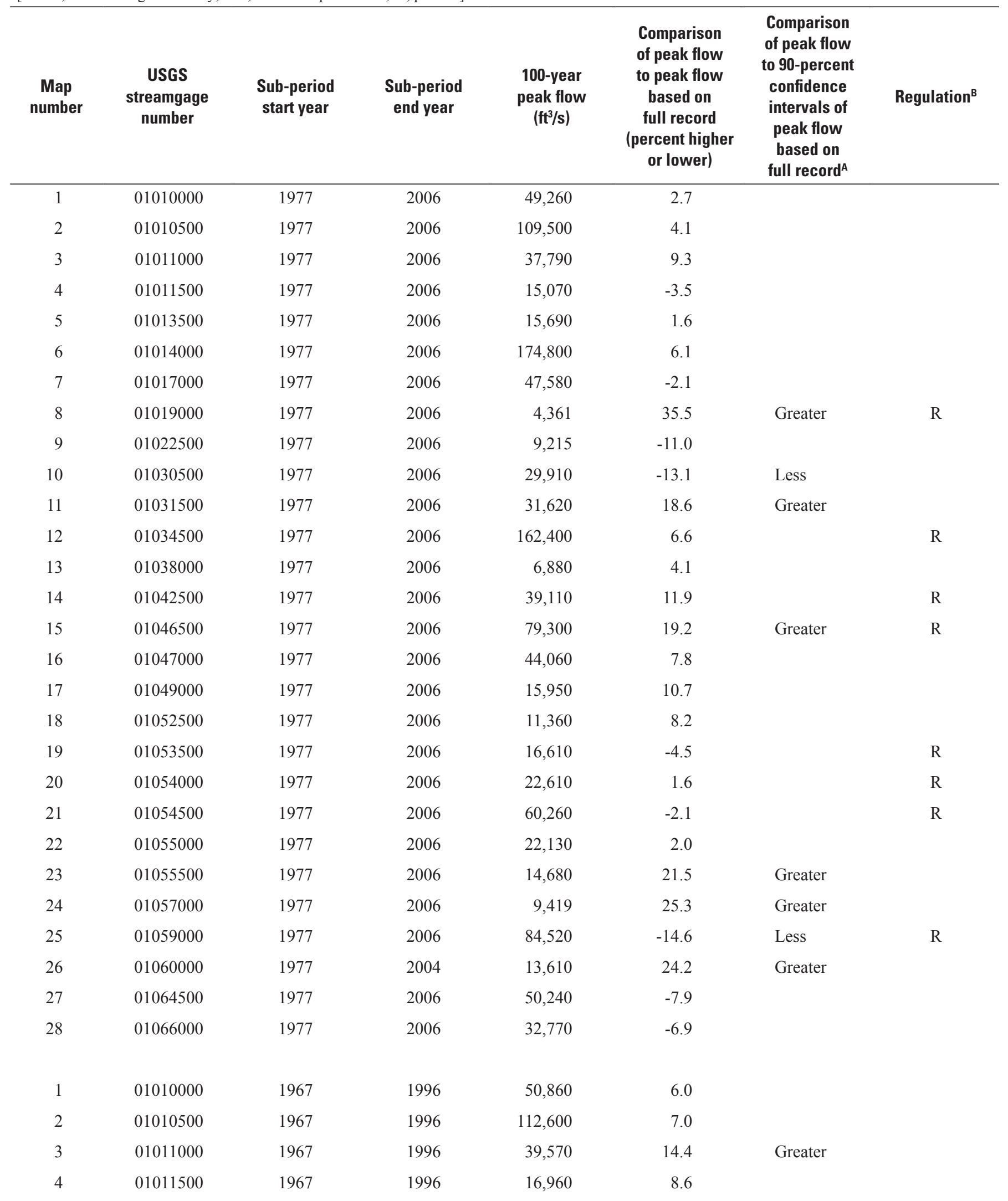


Table 4. Peak flows with 100-year recurrence intervals based on multiple 30-year sub-periods, and comparisons to 100-year peak flows based on full periods.

[USGS, U.S. Geological Survey; ft $3 / \mathrm{s}$, cubic feet per second; \%, percent]

\begin{tabular}{|c|c|c|c|c|c|c|c|}
\hline $\begin{array}{c}\text { Map } \\
\text { number }\end{array}$ & $\begin{array}{c}\text { USGS } \\
\text { streamgage } \\
\text { number }\end{array}$ & $\begin{array}{l}\text { Sub-period } \\
\text { start year }\end{array}$ & $\begin{array}{l}\text { Sub-period } \\
\text { end year }\end{array}$ & $\begin{array}{c}100-y e a r \\
\text { peak flow } \\
\left(\mathrm{ft}^{3} / \mathrm{s}\right)\end{array}$ & $\begin{array}{l}\text { Comparison } \\
\text { of peak flow } \\
\text { to peak flow } \\
\text { based on } \\
\text { full record } \\
\text { (percent higher } \\
\text { or lower) }\end{array}$ & $\begin{array}{c}\text { Comparison } \\
\text { of peak flow } \\
\text { to } 90 \text {-percent } \\
\text { confidence } \\
\text { intervals of } \\
\text { peak flow } \\
\text { based on } \\
\text { full record }\end{array}$ & Regulation $^{\mathrm{B}}$ \\
\hline 6 & 01014000 & 1967 & 1996 & 183,200 & 11.2 & Greater & \\
\hline 7 & 01017000 & 1967 & 1996 & 53,630 & 10.4 & Greater & \\
\hline 8 & 01019000 & 1967 & 1996 & 3,097 & -3.8 & & $\mathrm{R}$ \\
\hline 9 & 01022500 & 1967 & 1996 & 9,593 & -7.3 & & \\
\hline 12 & 01034500 & 1967 & 1996 & 173,800 & 14.1 & Greater & $\mathrm{R}$ \\
\hline 13 & 01038000 & 1967 & 1996 & 7,591 & 14.8 & & \\
\hline 14 & 01042500 & 1967 & 1996 & 41,800 & 19.6 & Greater & $\mathrm{R}$ \\
\hline 15 & 01046500 & 1967 & 1996 & 80,150 & 20.5 & Greater & $\mathrm{R}$ \\
\hline 16 & 01047000 & 1967 & 1996 & 44,410 & 8.7 & & \\
\hline 17 & 01049000 & 1967 & 1996 & 17,040 & 18.3 & Greater & \\
\hline 18 & 01052500 & 1967 & 1996 & 8,740 & -16.8 & Less & \\
\hline 19 & 01053500 & 1967 & 1996 & 17,350 & -0.3 & & $\mathrm{R}$ \\
\hline 25 & 01059000 & 1967 & 1996 & 84,130 & -15.0 & Less & $\mathrm{R}$ \\
\hline 26 & 01060000 & 1967 & 1996 & 12,330 & 12.5 & & \\
\hline 27 & 01064500 & 1967 & 1996 & 52,840 & -3.2 & & \\
\hline 28 & 01066000 & 1967 & 1996 & 33,910 & -3.7 & & \\
\hline 1 & 01010000 & 1957 & 1986 & 50,020 & 4.3 & & \\
\hline 2 & 01010500 & 1957 & 1986 & 114,700 & 9.0 & & \\
\hline 3 & 01011000 & 1957 & 1986 & 42,920 & 24.1 & Greater & \\
\hline 4 & 01011500 & 1957 & 1986 & 18,470 & 18.3 & Greater & \\
\hline 5 & 01013500 & 1957 & 1986 & 18,660 & 20.8 & Greater & \\
\hline 6 & 01014000 & 1957 & 1986 & 190,900 & 15.8 & Greater & \\
\hline 7 & 01017000 & 1957 & 1986 & 56,310 & 15.9 & Greater & \\
\hline 8 & 01019000 & 1957 & 1986 & 2,986 & -7.2 & & $\mathrm{R}$ \\
\hline
\end{tabular}


Table 4. Peak flows with 100-year recurrence intervals based on multiple 30-year sub-periods, and comparisons to 100-year peak flows based on full periods.

[USGS, U.S. Geological Survey; $\mathrm{ft}^{3} / \mathrm{s}$, cubic feet per second; \%, percent]

\begin{tabular}{|c|c|c|c|c|c|c|c|}
\hline $\begin{array}{c}\text { Map } \\
\text { number }\end{array}$ & $\begin{array}{c}\text { USGS } \\
\text { streamgage } \\
\text { number }\end{array}$ & $\begin{array}{l}\text { Sub-period } \\
\text { start year }\end{array}$ & $\begin{array}{l}\text { Sub-period } \\
\text { end year }\end{array}$ & $\begin{array}{c}100-y e a r \\
\text { peak flow } \\
\left(\mathrm{ft}^{3} / \mathrm{s}\right)\end{array}$ & $\begin{array}{l}\text { Comparison } \\
\text { of peak flow } \\
\text { to peak flow } \\
\text { based on } \\
\text { full record } \\
\text { (percent higher } \\
\text { or lower) }\end{array}$ & $\begin{array}{c}\text { Comparison } \\
\text { of peak flow } \\
\text { to } 90 \text {-percent } \\
\text { confidence } \\
\text { intervals of } \\
\text { peak flow } \\
\text { based on } \\
\text { full record }\end{array}$ & Regulation ${ }^{\mathrm{B}}$ \\
\hline 10 & 01030500 & 1957 & 1986 & 31,740 & -7.8 & Less & \\
\hline 11 & 01031500 & 1957 & 1986 & 28,760 & 7.9 & & \\
\hline 12 & 01034500 & 1957 & 1986 & 164,000 & 7.7 & & $\mathrm{R}$ \\
\hline 13 & 01038000 & 1957 & 1986 & 6,548 & -1.0 & & \\
\hline 17 & 01049000 & 1957 & 1986 & 13,920 & -3.4 & & \\
\hline 18 & 01052500 & 1957 & 1986 & 7,772 & -26.0 & Less & \\
\hline 19 & 01053500 & 1957 & 1986 & 16,760 & -3.7 & & $\mathrm{R}$ \\
\hline 20 & 01054000 & 1957 & 1986 & 17,840 & -19.9 & Less & $\mathrm{R}$ \\
\hline 21 & 01054500 & 1957 & 1986 & 57,170 & -7.1 & & $\mathrm{R}$ \\
\hline 22 & 01055000 & 1957 & 1986 & 21,200 & -2.3 & & \\
\hline 23 & 01055500 & 1957 & 1986 & 9,156 & -24.2 & Less & \\
\hline 2 & 01010500 & 1947 & 1976 & 101,600 & -3.4 & & \\
\hline 3 & 01011000 & 1947 & 1976 & 34,850 & 0.8 & & \\
\hline 5 & 01013500 & 1947 & 1976 & 17,650 & 14.2 & Greater & \\
\hline 6 & 01014000 & 1947 & 1976 & 174,900 & 6.1 & & \\
\hline 7 & 01017000 & 1947 & 1976 & 53,290 & 9.7 & & \\
\hline 8 & 01019000 & 1947 & 1976 & 2,563 & -20.4 & Less & $\mathrm{R}$ \\
\hline 10 & 01030500 & 1947 & 1976 & 32,870 & -4.5 & & \\
\hline 11 & 01031500 & 1947 & 1976 & 27,940 & 4.8 & & \\
\hline 12 & 01034500 & 1947 & 1976 & 147,100 & -3.4 & & $\mathrm{R}$ \\
\hline 13 & 01038000 & 1947 & 1976 & 5,817 & -12.0 & & \\
\hline 16 & 01047000 & 1947 & 1976 & 43,210 & 5.7 & & \\
\hline
\end{tabular}


Table 4. Peak flows with 100-year recurrence intervals based on multiple 30-year sub-periods, and comparisons to 100-year peak flows based on full periods.

[USGS, U.S. Geological Survey; ft $3 / \mathrm{s}$, cubic feet per second; \%, percent]

\begin{tabular}{|c|c|c|c|c|c|c|c|}
\hline $\begin{array}{c}\text { Map } \\
\text { number }\end{array}$ & $\begin{array}{c}\text { USGS } \\
\text { streamgage } \\
\text { number }\end{array}$ & $\begin{array}{l}\text { Sub-period } \\
\text { start year }\end{array}$ & $\begin{array}{l}\text { Sub-period } \\
\text { end year }\end{array}$ & $\begin{array}{c}100 \text {-year } \\
\text { peak flow } \\
\left(\mathrm{ft}^{3} / \mathrm{s}\right)\end{array}$ & $\begin{array}{l}\text { Comparison } \\
\text { of peak flow } \\
\text { to peak flow } \\
\text { based on } \\
\text { full record } \\
\text { (percent higher } \\
\text { or lower) }\end{array}$ & $\begin{array}{c}\text { Comparison } \\
\text { of peak flow } \\
\text { to } 90 \text {-percent } \\
\text { confidence } \\
\text { intervals of } \\
\text { peak flow } \\
\text { based on } \\
\text { full record }\end{array}$ & Regulation $^{B}$ \\
\hline 18 & 01052500 & 1947 & 1976 & 8,447 & -19.6 & Less & \\
\hline 19 & 01053500 & 1947 & 1976 & 16,660 & -4.3 & & $\mathrm{R}$ \\
\hline 20 & 01054000 & 1947 & 1976 & 19,770 & -11.2 & Less & $\mathrm{R}$ \\
\hline 21 & 01054500 & 1947 & 1976 & 60,540 & -1.7 & & $\mathrm{R}$ \\
\hline 24 & 01057000 & 1947 & 1976 & 6,325 & -15.8 & Less & \\
\hline 25 & 01059000 & 1947 & 1976 & 87,700 & -11.4 & Less & $\mathrm{R}$ \\
\hline 27 & 01064500 & 1947 & 1976 & 65,340 & 19.8 & Greater & \\
\hline 28 & 01066000 & 1947 & 1976 & 38,360 & 8.9 & & \\
\hline 3 & 01011000 & 1937 & 1966 & 30,280 & -12.4 & Less & \\
\hline 5 & 01013500 & 1937 & 1966 & 15,290 & -1.0 & & \\
\hline 6 & 01014000 & 1937 & 1966 & 153,300 & -7.0 & & \\
\hline 16 & 01047000 & 1937 & 1966 & 36,440 & -10.8 & & \\
\hline 17 & 01049000 & 1937 & 1966 & 12,410 & -13.9 & Less & \\
\hline 19 & 01053500 & 1937 & 1966 & 16,530 & -5.0 & & $\mathrm{R}$ \\
\hline 20 & 01054000 & 1937 & 1966 & 19,060 & -14.4 & Less & $\mathrm{R}$ \\
\hline 21 & 01054500 & 1937 & 1966 & 59,810 & -2.8 & & $\mathrm{R}$ \\
\hline 22 & 01055000 & 1937 & 1966 & 22,940 & 5.7 & & \\
\hline 24 & 01057000 & 1937 & 1966 & 6,713 & -10.7 & & \\
\hline 25 & 01059000 & 1937 & 1966 & 87,100 & -12.0 & Less & $\mathrm{R}$ \\
\hline 27 & 01064500 & 1937 & 1966 & 57,740 & 5.8 & & \\
\hline 28 & 01066000 & 1937 & 1966 & 36,060 & 2.4 & & \\
\hline 6 & 01014000 & 1927 & 1956 & 140,600 & -14.7 & Less & \\
\hline 10 & 01030500 & 1927 & 1956 & 33,070 & -3.9 & & \\
\hline
\end{tabular}


Table 4. Peak flows with 100-year recurrence intervals based on multiple 30-year sub-periods, and comparisons to 100-year peak flows based on full periods.

[USGS, U.S. Geological Survey; $\mathrm{ft}^{3} / \mathrm{s}$, cubic feet per second; \%, percent]

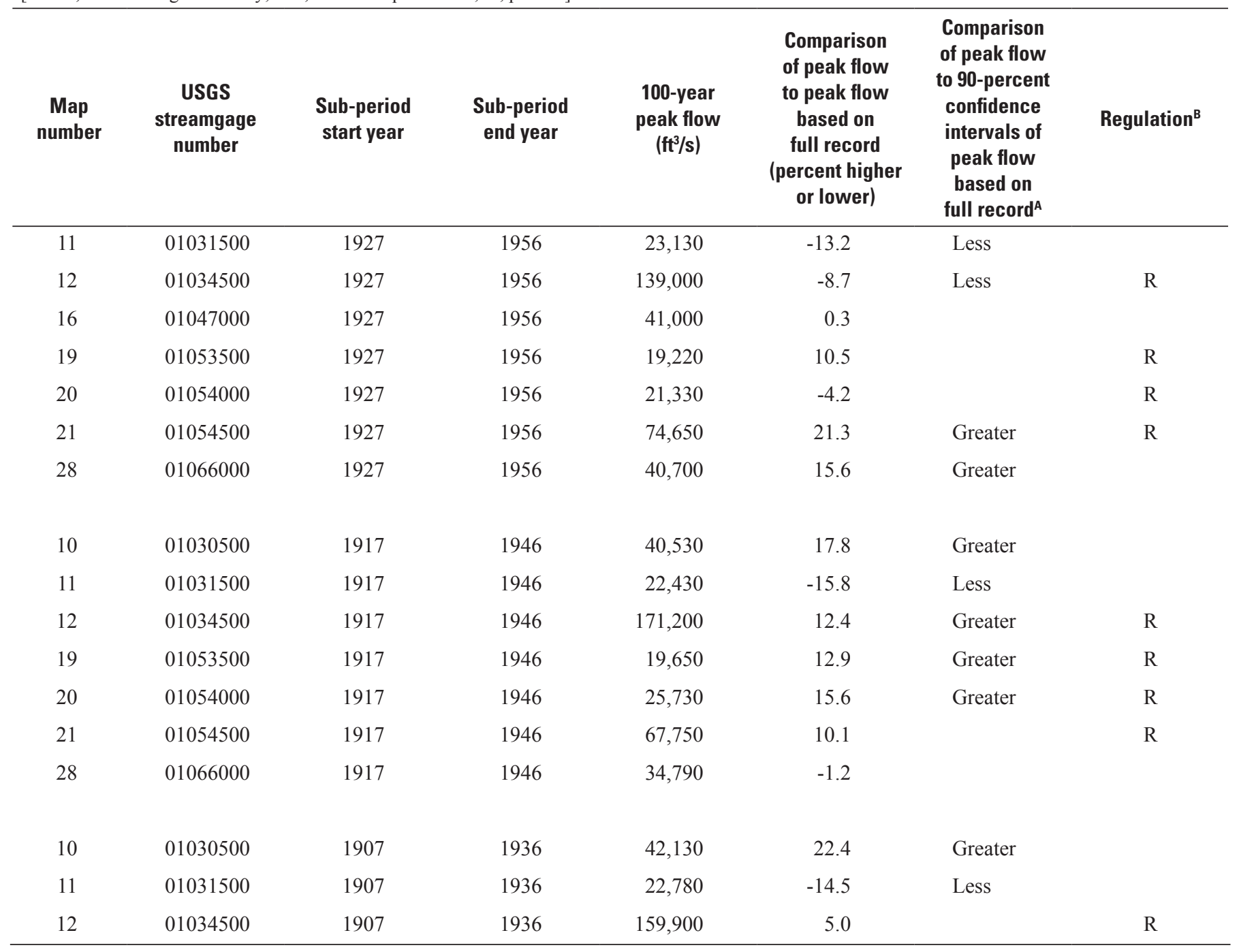

${ }^{\mathrm{A}}$ Blank indicates within 90-percent confidence intervals.

${ }^{\text {B } U n r e g u l a t e d ~ u n l e s s ~ n o t e d ~(s t r e a m g a g e ~ h a s ~ d r a i n a g e ~ b a s i n ~ w i t h ~ l e s s ~ t h a n ~} 4.5$ million cubic feet of usable storage per mile (Benson, 1962)). 
Table 5. Peak flows with 100-year recurrence intervals based on the sub-periods 1971 to 2006 and start-of-record to 1970, and comparisons to 100-year peak flows based on full periods.

[USGS, U.S. Geological Survey; $\mathrm{ft}^{3} / \mathrm{s}$, cubic feet per second]

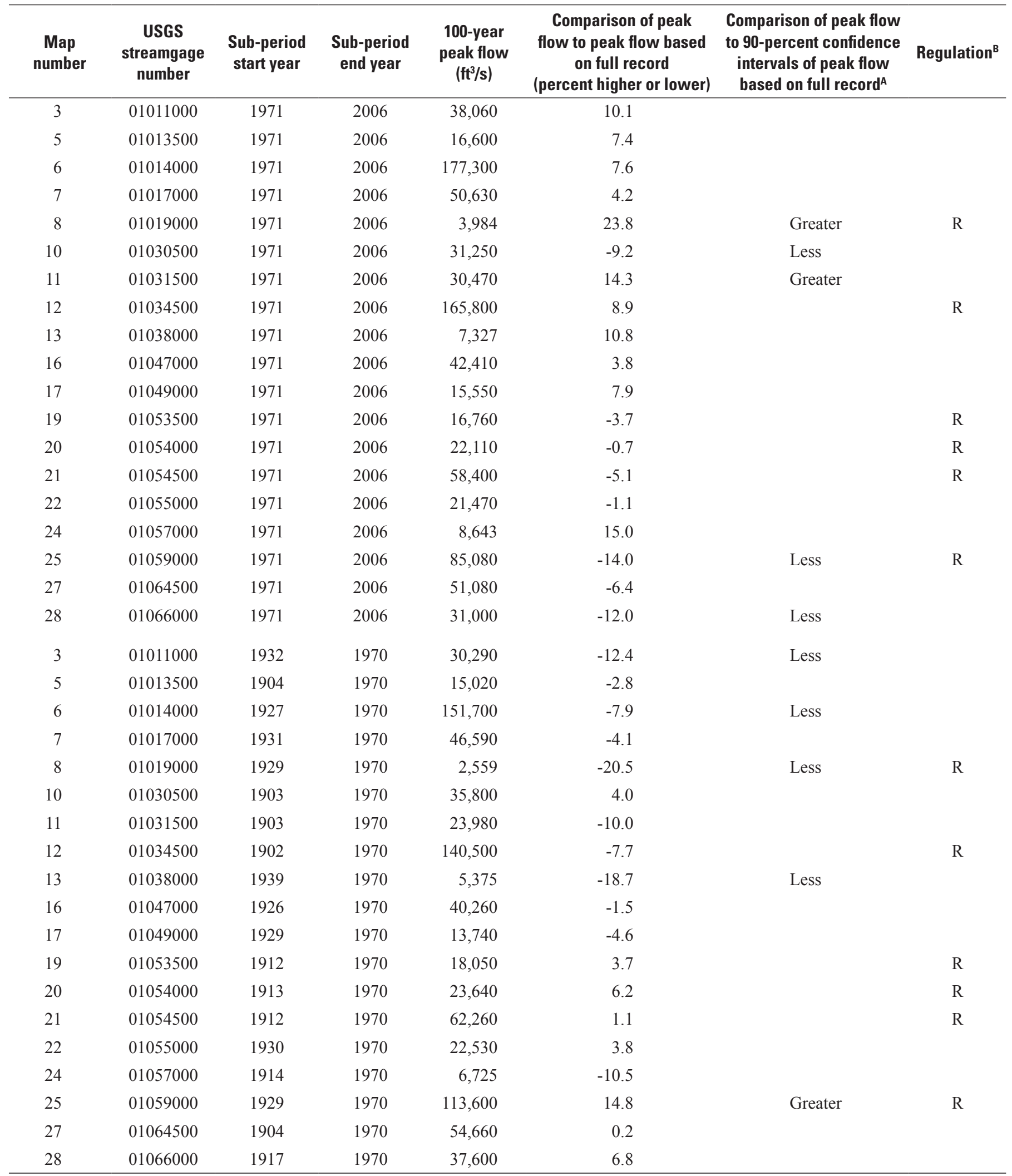

${ }^{\mathrm{A}}$ Blank indicates within 90-percent confidence intervals.

${ }^{\text {B } U n r e g u l a t e d ~ u n l e s s ~ n o t e d ~(s t r e a m g a g e ~ h a s ~ d r a i n a g e ~ b a s i n ~ w i t h ~ l e s s ~ t h a n ~} 4.5$ million cubic feet of usable storage per mile (Benson, 1962)). 
Table 6. Peak flows with 5-year recurrence intervals based on multiple 30-year sub-periods, and comparisons to 5-year peak flows based on full periods.

[USGS, U.S. Geological Survey; $\mathrm{ft}^{3} / \mathrm{s}$, cubic feet per second]

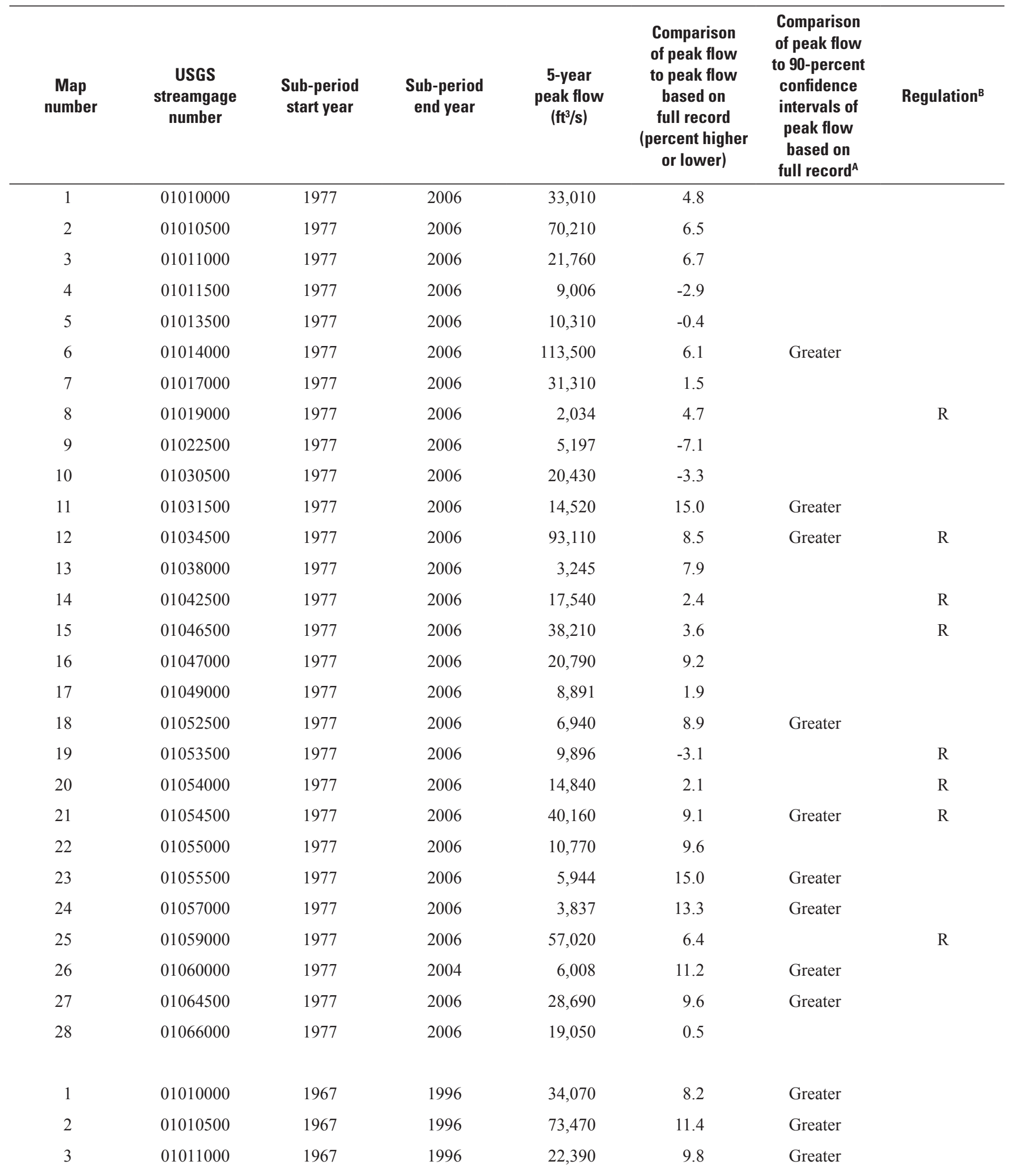


Table 6. Peak flows with 5-year recurrence intervals based on multiple 30-year sub-periods, and comparisons to 5-year peak flows based on full periods.

[USGS, U.S. Geological Survey; $\mathrm{ft}^{3} / \mathrm{s}$, cubic feet per second]

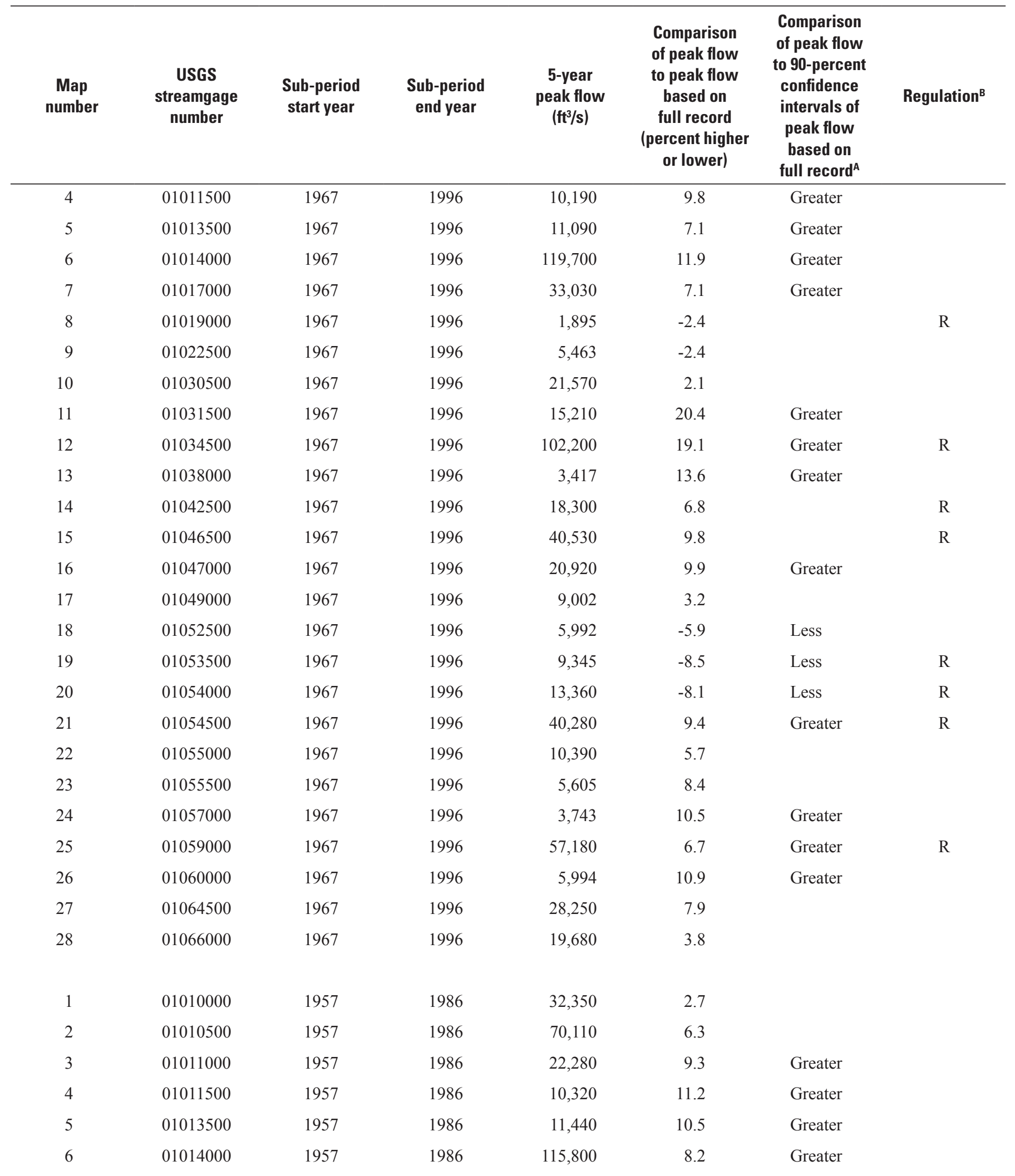


Table 6. Peak flows with 5-year recurrence intervals based on multiple 30-year sub-periods, and comparisons to 5-year peak flows based on full periods.

[USGS, U.S. Geological Survey; $\mathrm{ft}^{3} / \mathrm{s}$, cubic feet per second]

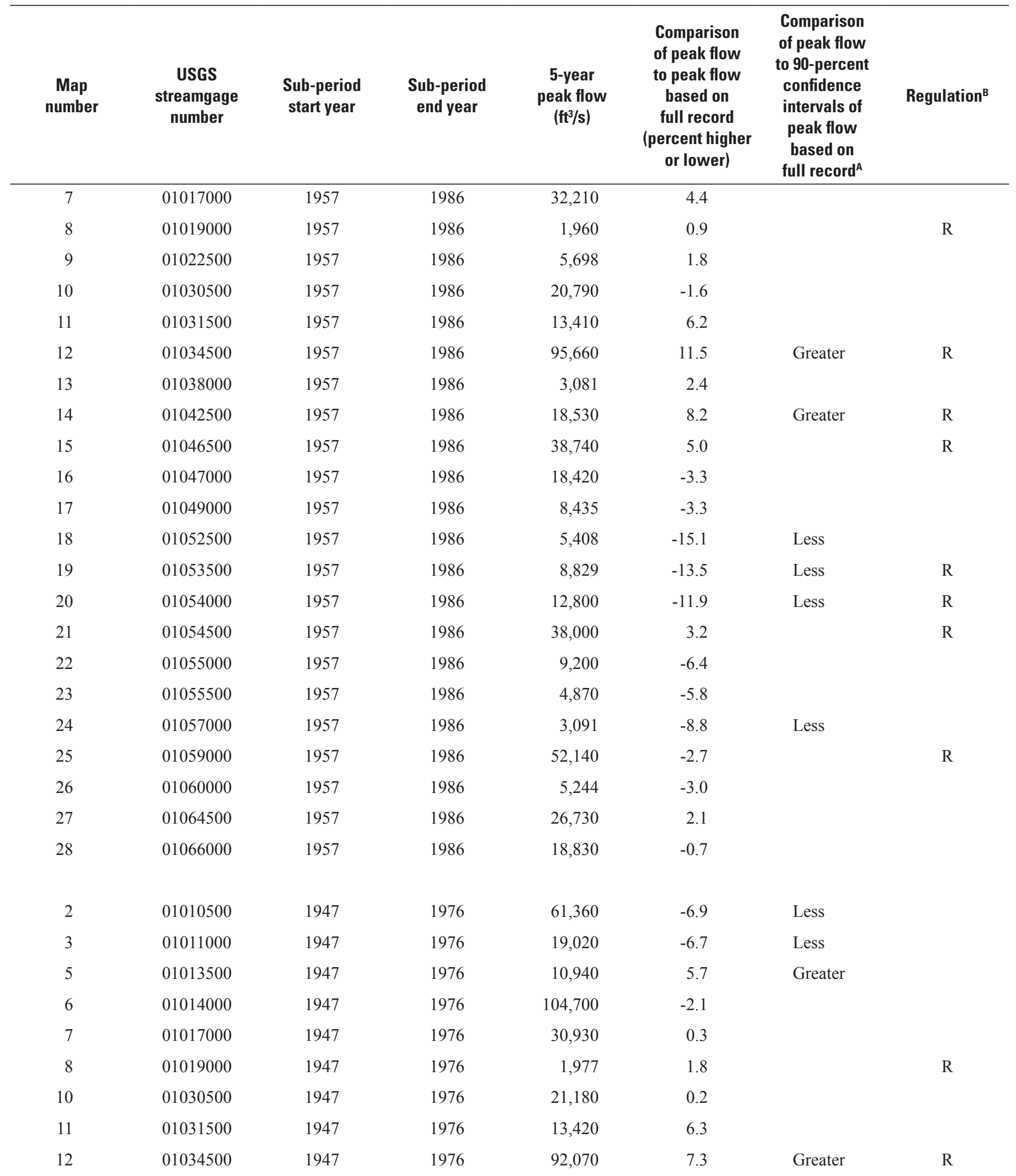


Table 6. Peak flows with 5-year recurrence intervals based on multiple 30-year sub-periods, and comparisons to 5-year peak flows based on full periods.

[USGS, U.S. Geological Survey; $\mathrm{ft}^{3} / \mathrm{s}$, cubic feet per second]

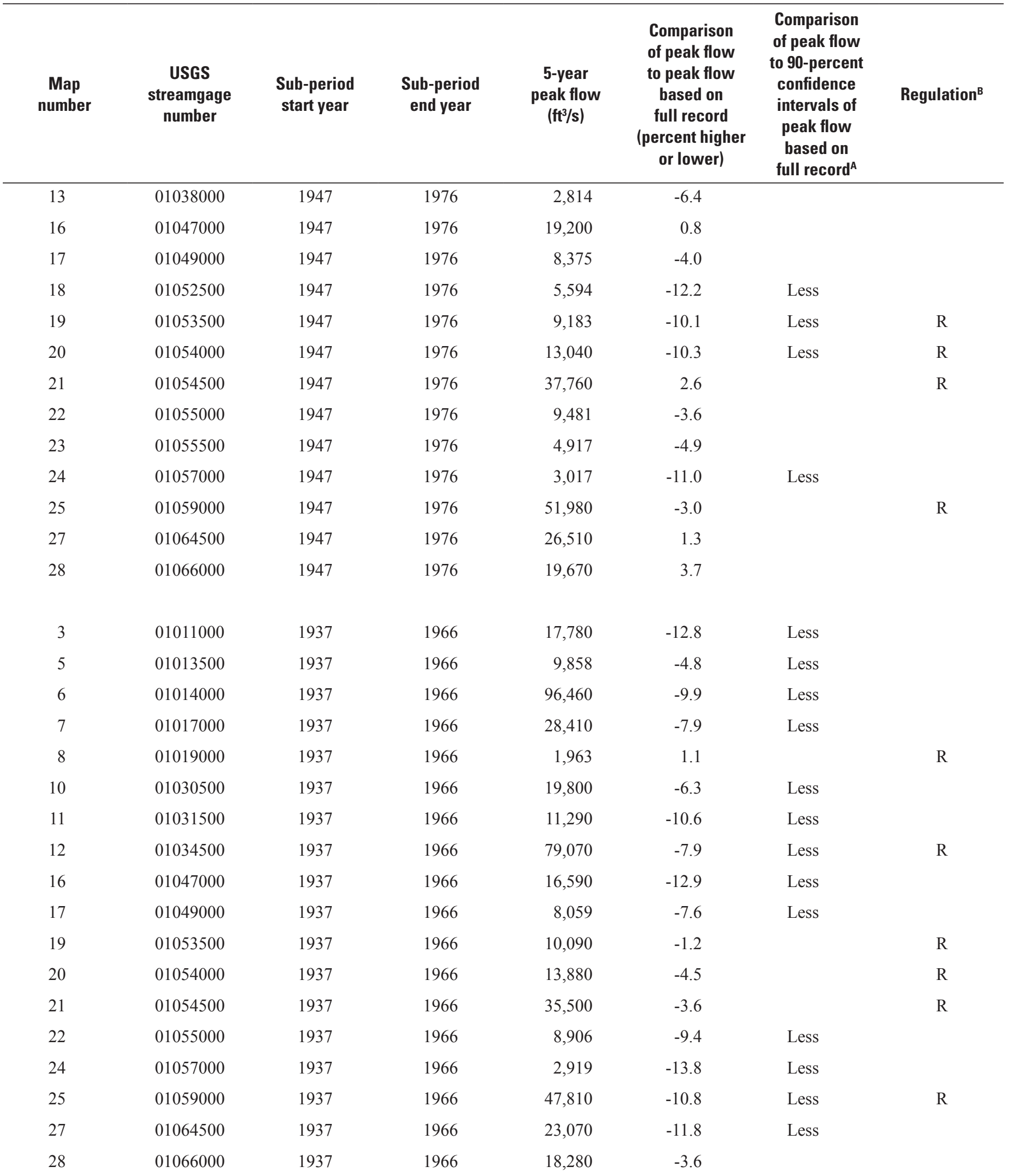




\section{Historical Changes in Annual Peak Flows in Maine and Implications for Flood-Frequency Analyses}

Table 6. Peak flows with 5-year recurrence intervals based on multiple 30-year sub-periods, and comparisons to 5-year peak flows based on full periods.

[USGS, U.S. Geological Survey; $\mathrm{ft}^{3} / \mathrm{s}$, cubic feet per second]

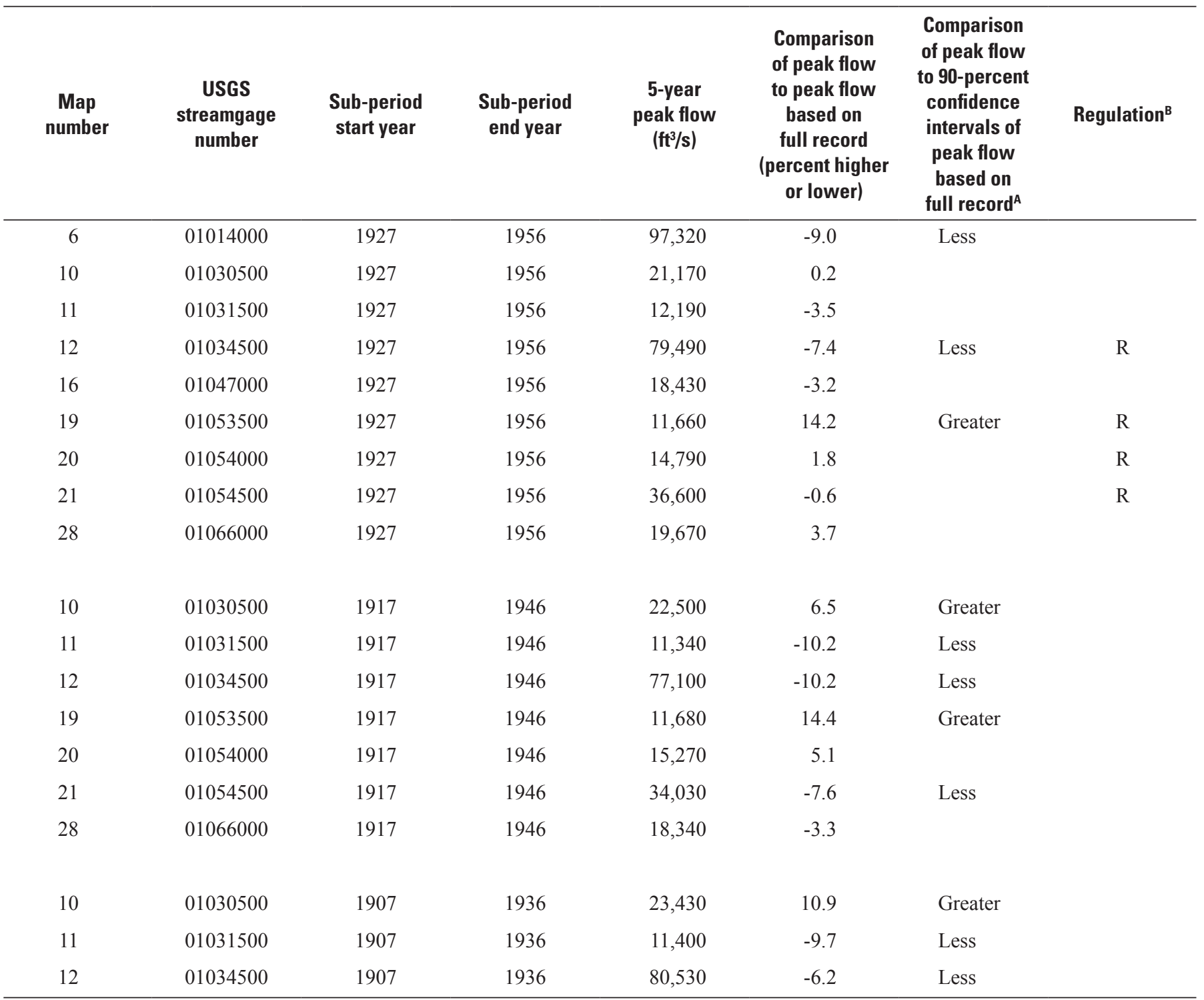

${ }^{\text {A }}$ Blank indicates within 90-percent confidence intervals.

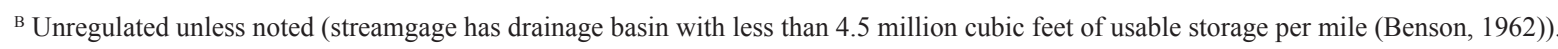


Table 7. Peak flows with 5-year recurrence intervals based on the sub-periods 1971 to 2006 and start-of-record to 1970, and comparisons to 5 -year peak flows based on full periods.

[USGS, U.S. Geological Survey; $\mathrm{ft}^{3} / \mathrm{s}$, cubic feet per second]

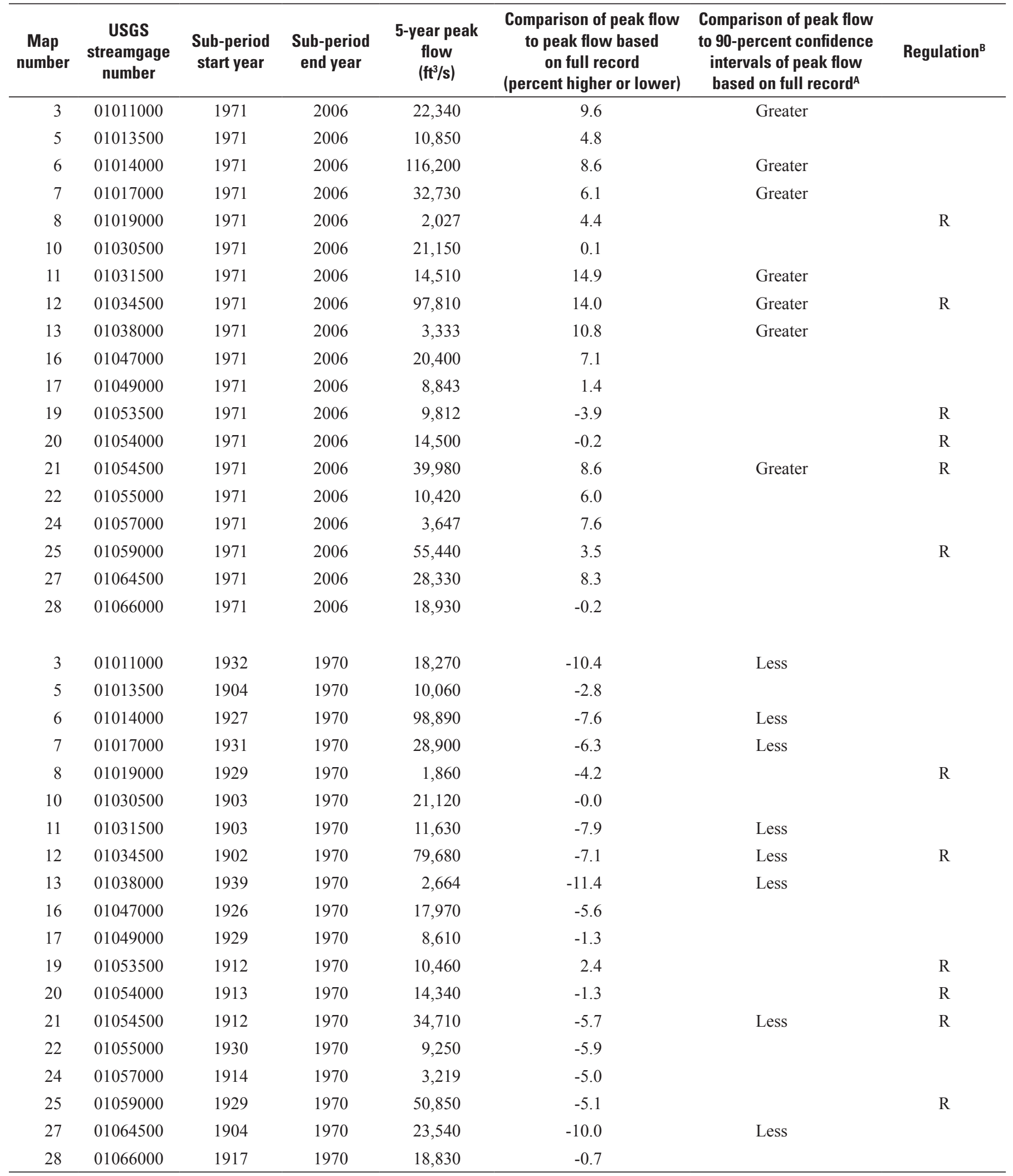

\footnotetext{
${ }^{\text {A }}$ Blank indicates within 90-percent confidence intervals.
}

${ }^{\text {B } U n r e g u l a t e d ~ u n l e s s ~ n o t e d ~(s t r e a m g a g e ~ h a s ~ d r a i n a g e ~ b a s i n ~ w i t h ~ l e s s ~ t h a n ~} 4.5$ million cubic feet of usable storage per mile (Benson, 1962)). 
Table 8. Median differences between peak flows for selected recurrence intervals based on sub-periods and peak flows based on full periods of record.

[percent represents percent higher or lower than full-period peak flows]

\begin{tabular}{|c|c|c|c|c|c|c|c|}
\hline \multirow[b]{2}{*}{$\begin{array}{l}\text { Sub-period } \\
\text { start year }\end{array}$} & \multirow[b]{2}{*}{$\begin{array}{l}\text { Sub-period } \\
\text { end year }\end{array}$} & \multirow[b]{2}{*}{$\begin{array}{c}\begin{array}{c}\text { Total } \\
\text { number } \\
\text { of } \\
\text { streamgages }\end{array}\end{array}$} & \multirow[b]{2}{*}{$\begin{array}{c}\text { Number } \\
\text { of } \\
\text { unregulated } \\
\text { streamgages }\end{array}$} & \multicolumn{4}{|c|}{ Median differences } \\
\hline & & & & $\begin{array}{c}\text { 100-year } \\
\text { peak flows, } \\
\text { all } \\
\text { streamgages } \\
\text { (percent) }\end{array}$ & $\begin{array}{c}\text { 100-year } \\
\text { peak flows, } \\
\text { unregulated } \\
\text { streamgages } \\
\text { (percent) }\end{array}$ & $\begin{array}{c}\text { 5-year } \\
\text { peak flows, } \\
\text { all } \\
\text { streamgages } \\
\text { (percent) }\end{array}$ & $\begin{array}{c}\text { 5-year } \\
\text { peak flows, } \\
\text { unregulated } \\
\text { streamgages } \\
\text { (percent) }\end{array}$ \\
\hline 1977 & 2006 & 28 & 20 & 4.1 & 4.1 & 6.2 & 6.6 \\
\hline 1967 & 1996 & 28 & 20 & 7.8 & 8.7 & 8.1 & 8.3 \\
\hline 1957 & 1986 & 28 & 20 & -1.6 & 0.8 & 2.0 & 2.0 \\
\hline 1947 & 1976 & 22 & 16 & -3.4 & 2.8 & -2.6 & -2.8 \\
\hline 1937 & 1966 & 18 & 12 & -10.8 & -8.8 & -7.9 & -9.6 \\
\hline 1927 & 1956 & 9 & 5 & -3.9 & -3.9 & -0.6 & -3.2 \\
\hline 1971 & 2006 & 19 & 13 & 4.2 & 7.4 & 6.1 & 7.1 \\
\hline Start of record & 1970 & 19 & 13 & -2.8 & -4.1 & -5.6 & -5.9 \\
\hline
\end{tabular}

Table 9. Number of streamgages with 100-year peak flows based on sub-periods that are outside of 90-percent confidence intervals of 100-year peak flows based on full periods of record.

\begin{tabular}{|c|c|c|c|c|c|c|c|}
\hline \multirow{2}{*}{$\begin{array}{l}\text { Sub-period } \\
\text { start year }\end{array}$} & \multirow{2}{*}{$\begin{array}{l}\text { Sub-period } \\
\text { end year }\end{array}$} & \multirow{2}{*}{$\begin{array}{c}\begin{array}{c}\text { Total } \\
\text { number } \\
\text { of }\end{array} \\
\text { streamgages }\end{array}$} & \multirow{2}{*}{$\begin{array}{c}\text { Number } \\
\text { of } \\
\text { unregulated } \\
\text { streamgages }\end{array}$} & \multicolumn{2}{|c|}{$\begin{array}{l}\text { Greater than 90-percent } \\
\text { confidence interval }\end{array}$} & \multicolumn{2}{|c|}{$\begin{array}{l}\text { Less than } 90 \text {-percent } \\
\text { confidence interval }\end{array}$} \\
\hline & & & & $\begin{array}{c}\text { All } \\
\text { streamgages }\end{array}$ & $\begin{array}{l}\text { Unregulated } \\
\text { streamgages }\end{array}$ & $\begin{array}{c}\text { All } \\
\text { streamgages }\end{array}$ & $\begin{array}{l}\text { Unregulated } \\
\text { streamgages }\end{array}$ \\
\hline 1977 & 2006 & 28 & 20 & 6 & 4 & 2 & 1 \\
\hline 1967 & 1996 & 28 & 20 & 10 & 7 & 3 & 1 \\
\hline 1957 & 1986 & 28 & 20 & 6 & 5 & 6 & 4 \\
\hline 1947 & 1976 & 22 & 16 & 2 & 2 & 6 & 3 \\
\hline 1937 & 1966 & 18 & 12 & 0 & 0 & 8 & 4 \\
\hline 1927 & 1956 & 9 & 5 & 2 & 1 & 3 & 2 \\
\hline 1971 & 2006 & 19 & 13 & 2 & 1 & 3 & 2 \\
\hline Start of record & 1970 & 19 & 13 & 1 & 0 & 4 & 3 \\
\hline
\end{tabular}

Peak flows for selected recurrence intervals are subject to uncertainty because the annual peak flows used in the computations are only a sample of a larger population (Interagency Advisory Committee on Water Data, 1982). Confidence intervals are a measure of the uncertainty of these computations. With a 90-percent confidence interval, one is 90-percent confident that the true peak flow is between the lower and upper 90-percent confidence limits. The 100-year confidence intervals are larger than the 5-year confidence intervals because more uncertainty is associated with them.

The 1967 to 1996 sub-period yielded the highest 100- and 5 -year peak flows overall when compared with peak flows based on the full period of record (table 8, figs. 4 and 5). The median difference for all 28 streamgages is 8 percent for both 100- and 5-year peak flows. The 1977-2006 and 1971-2006 sub-periods overall yielded higher flows but not as high as the 1967-96 sub-period; the median differences for all streamgages for both periods (1977-2006 and 1971-2006) are 4 percent for 100-year peak flows and 6 percent for 5-year peak flows. The 1937-66 sub-period had the lowest 100- and 5 -year peak flows overall. The median differences are -11 percent for 100-year peak flows and -8 percent for 5-year peak flows. Differences between the sub-periods and the full periods based on the 20 unregulated streamgages are similar to differences based on all 28 streamgages (table 8). Magnitudes of peak-flow differences (between peak flows based on the 
Table 10. Number of streamgages with 5-year peak flows based on sub-periods that are outside of 90-percent confidence intervals of 5 -year peak flows based on full records.

\begin{tabular}{|c|c|c|c|c|c|c|c|}
\hline \multirow{2}{*}{$\begin{array}{l}\text { Sub-period } \\
\text { start year }\end{array}$} & \multirow{2}{*}{$\begin{array}{l}\text { Sub-period } \\
\text { end year }\end{array}$} & \multirow{2}{*}{$\begin{array}{c}\text { Total } \\
\text { number of } \\
\text { streamgages }\end{array}$} & \multirow{2}{*}{$\begin{array}{c}\text { Number of } \\
\text { unregulated } \\
\text { streamgages }\end{array}$} & \multicolumn{2}{|c|}{$\begin{array}{l}\text { Greater than 90-percent } \\
\text { confidence interval }\end{array}$} & \multicolumn{2}{|c|}{$\begin{array}{l}\text { Less than 90-percent confidence } \\
\text { interval }\end{array}$} \\
\hline & & & & $\begin{array}{c}\text { All } \\
\text { streamgages }\end{array}$ & $\begin{array}{l}\text { Unregulated } \\
\text { streamgages }\end{array}$ & $\begin{array}{c}\text { All } \\
\text { streamgages }\end{array}$ & $\begin{array}{l}\text { Unregulated } \\
\text { streamgages }\end{array}$ \\
\hline 1977 & 2006 & 28 & 20 & 9 & 7 & 0 & 0 \\
\hline 1967 & 1996 & 28 & 20 & 15 & 12 & 3 & 1 \\
\hline 1957 & 1986 & 28 & 20 & 6 & 4 & 4 & 2 \\
\hline 1947 & 1976 & 22 & 16 & 2 & 1 & 6 & 4 \\
\hline 1937 & 1966 & 18 & 12 & 0 & 0 & 13 & 11 \\
\hline 1927 & 1956 & 9 & 5 & 1 & 0 & 2 & 1 \\
\hline 1971 & 2006 & 19 & 13 & 7 & 5 & 0 & 0 \\
\hline Start of record & 1970 & 19 & 13 & 0 & 0 & 8 & 6 \\
\hline
\end{tabular}
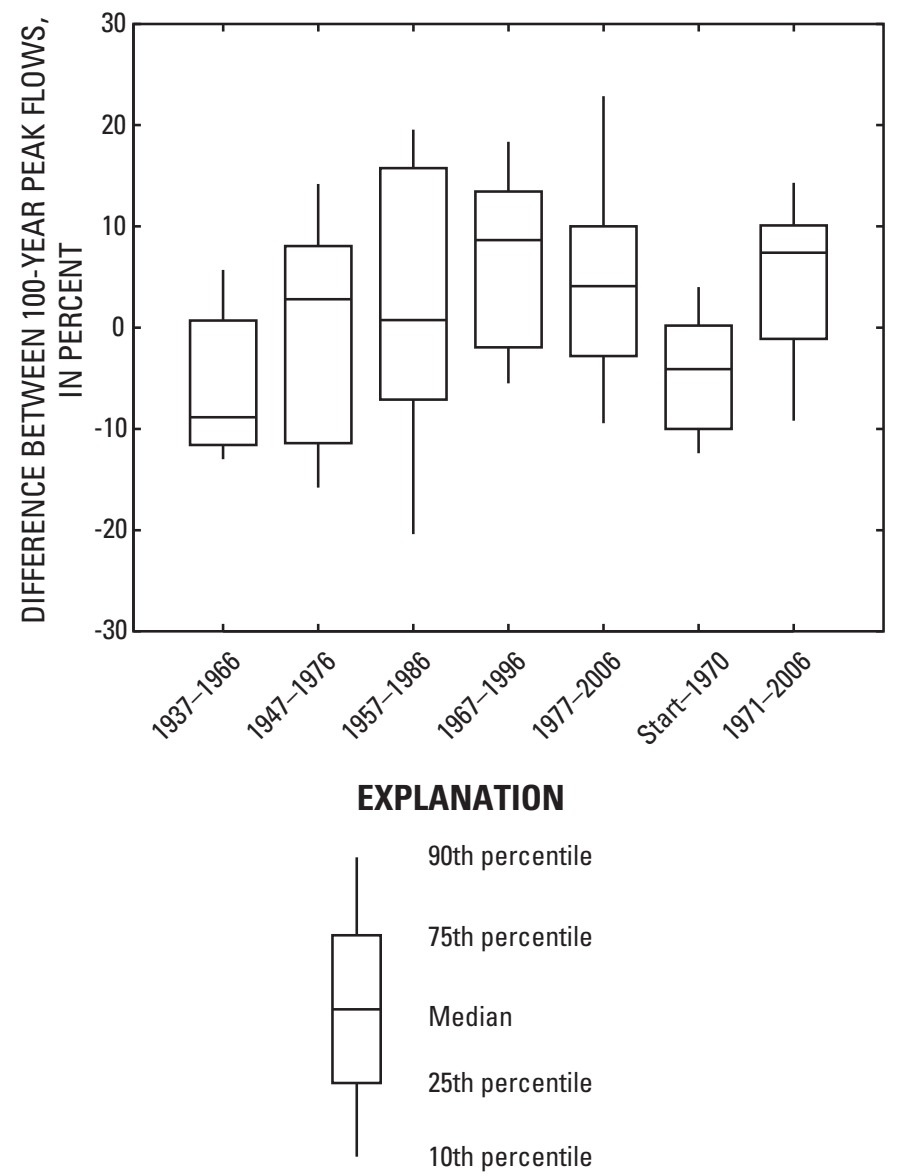

Figure 4. Distribution of differences for various rivers between 100 -year peak flows based on selected sub-periods and 100-year peak flows based on full periods of record.

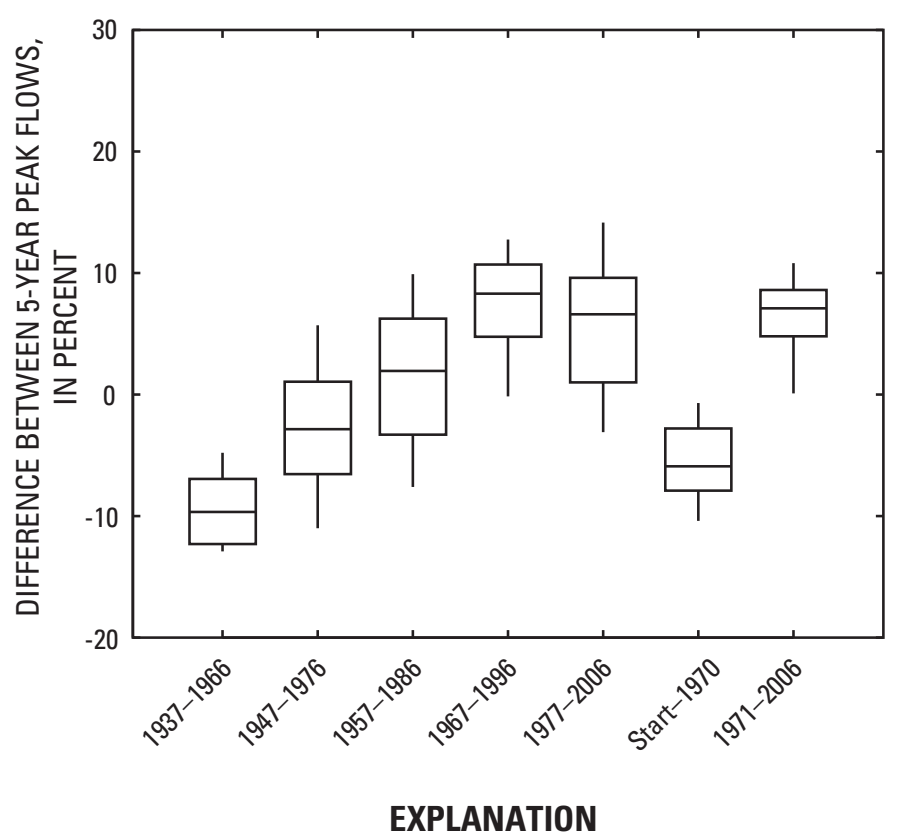

90th percentile

75th percentile

Median

25th percentile

10th percentile
Figure 5. Distribution of differences for various rivers between 5 -year peak flows based on selected sub-periods and 5-year peak flows based on full periods of record. 
sub-periods and those based on the full periods) vary more among streamgages for 100-year peak flows than for 5-year peak flows (figs. 4 and 5). The boxplots in figures 4 and 5 show the 10th, 25th, 50th (median), 75th, and 90th percentiles of differences for all available rivers, for each sub-period.

The 1967-1996 sub-period produced the most streamgages (10 of 28) with 100-year peak flows higher than the 90-percent confidence intervals of the peak flows computed from full periods of record (table 9). The 1967-96 sub-period also produced the most streamgages (15 of 28) with 5-year peak flows higher than the full-period 90-percent confidence intervals (table 10). The 1937-66 sub-period yielded the most streamgages ( 8 of 18) with 100 -year peak flows lower than the 90-percent confidence intervals of the full-period peak flows. The 1937-66 sub-period also yielded the most streamgages ( 13 of 18 ) with 5-year peak flows less than the 90-percent confidence intervals. More streamgages had 5-year peak flows outside the confidence intervals for these two sub-periods (1967-96 and 1937-66) than had 100 -year peak flows outside the confidence intervals. This is likely due to the lower uncertainty for the 5-year peak flows than for the 100-year peak flows (table 1). The 1971-2006 sub-period also produced more streamgages ( 7 of 19) with 5 -year peak flows greater than the full-record confidence intervals than streamgages with 100 -year peak flows greater than full-record confidence intervals (2 of 19) (tables 9 and 10). The older sub-period (start-of-record to 1970) produced more streamgages ( 8 of 19) with 5-year peak flows less than the confidence intervals than with 100 -year peak flows (4 of 19) less than the confidence intervals. Overall, for the various time periods considered, the relative number of total (regulated and unregulated) streamgages with peak flows outside the confidence intervals is consistent with the relative number of unregulated streamgages with peak flows outside the confidence intervals (tables 9 and 10).

\section{Detailed Results for 100-Year Peak Flows}

For 6 of 28 streamgages, the 100 -year peak flows based on the 1977-2006 sub-period were greater than the 90-percent confidence intervals based on full periods, and for 2 streamgages, the peak flows were less than the confidence intervals (table 4). The two streamgages with peak flows less than the confidence intervals had high-outlier peak flows early in their records. One of six streamgages with peaks greater than the confidence intervals had a high-outlier peak flow during the 1977-2006 sub-period. High-outlier peak flows for the full period of record, identified as outliers by use of the guidelines (Bulletin 17B) of the Interagency Advisory Committee on Water Data (1982), were present for five of the streamgages. The high-outlier peaks are approximately three standard deviations (depending on the length of record) above the mean of all the annual peaks. Peak flows with 100-year recurrence intervals based on the 1977-2006 sub-period ranged from 13 percent lower to 25 percent higher than flows based on full records at the 20 unregulated streamgages.

For 10 of 28 streamgages, 100 -year peak flows based on the 1967-96 sub-period were greater than the 90-percent confidence intervals based on full periods of record, and for 3 streamgages, flows were less than the confidence intervals (table 4). The streamgages with peak flows greater than the confidence intervals are spread throughout the State (fig. 6); all three streamgages (streamgages 18, 20, and 25) with peak flows lower than the confidence intervals drain the upper Androscoggin River Basin. Two of the three streamgages with peak flows less than the confidence intervals had highoutlier peak flows outside of the 1967-96 sub-period. One of 10 streamgages with peaks greater than the confidence interval had a high-outlier peak within the sub-period. Peak flows based on the sub-period 1967-96 ranged from 17 percent lower to 26 percent higher than flows based on full records at the 20 unregulated streamgages.

For 6 of 28 streamgages, the 100-year peak flows based on the 1957-1986 sub-period were greater than the 90-percent confidence intervals based on full periods of record, and for 6 streamgages, flows were less than the confidence intervals (table 4). For two streamgages (of 22 total), the 100-year peak flows based on the 1947-1976 sub-period were greater than the confidence intervals, and for six streamgages, flows were less than the confidence intervals.

For 8 of 18 streamgages, the 100 -year peak flows based on the 1937-66 sub-period were less than the full-period 90-percent confidence intervals (table 4); no streamgages had flows greater than the confidence intervals. The eight streamgages with peak flows less than the confidence intervals are spread throughout the State (fig. 7). Three of the eight streamgages had high-outlier peak flows outside of the 1937-66 sub-period. For the limited number of streamgages with records from the 1927-56, 1917-46, and 1907-36 sub-periods, peak flows were both greater and less than the 90-percent confidence intervals based on full periods (table 4).

For 2 of 19 streamgages, 100-year peak flows based on the 1971-2006 sub-period were greater than the full-period 90-percent confidence intervals, and for 3 streamgages, flows were less than the confidence intervals (table 5, fig. 8). One of the two streamgages with peaks greater than the confidence interval had a high-outlier peak within the 1971-2006 sub-period. All three of the streamgages with peak flows less than the confidence intervals had high-outlier peak flows prior to the 1971-2006 sub-period. Peak flows based on the sub-period ranged from 12 percent lower to 15 percent higher than flows based on the full period at the 13 unregulated streamgages. For four streamgages, the 100 -year peak flows based on flows from start-of-record to 1970 were less than the full-period 90-percent confidence intervals, and for one streamgage, flows were greater than the confidence interval (table 5, fig. 9). This latter streamgage had a high outlier in the sub-period start-of-record to 1970. 


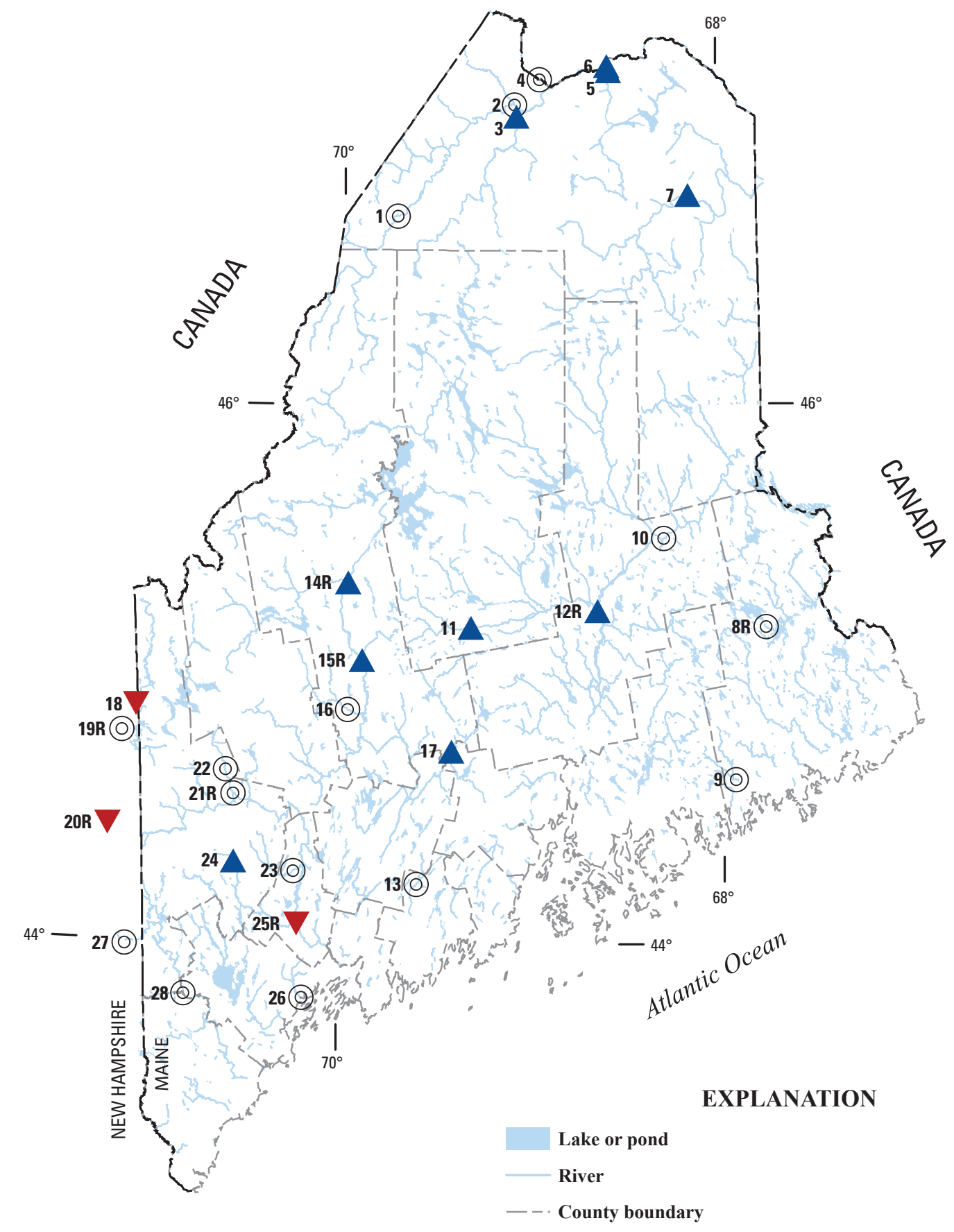

Station and reference number-Symbol indicates how 100-year peak flows based on the period 1967-96 compare to those based on the full record

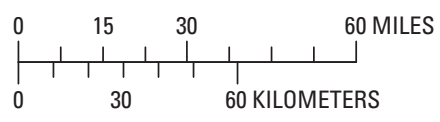

Base from U.S. Geological Survey digital files, Universal Transverse Mercator projection, zone 19
24 Greater than 90-percent confidence interval of full record

10 (O) Within 90-percent confidence interval of full record

18 Less than 90-percent confidence interval of full record

" $\mathrm{R}$ " in the reference number indicates station streamflow is regulated

Figure 6. Geographic distribution of 100-year peak flows based on the 1967 to 1996 sub-period that are outside the 90 -percent confidence intervals of 100 -year peak flows based on full periods. 


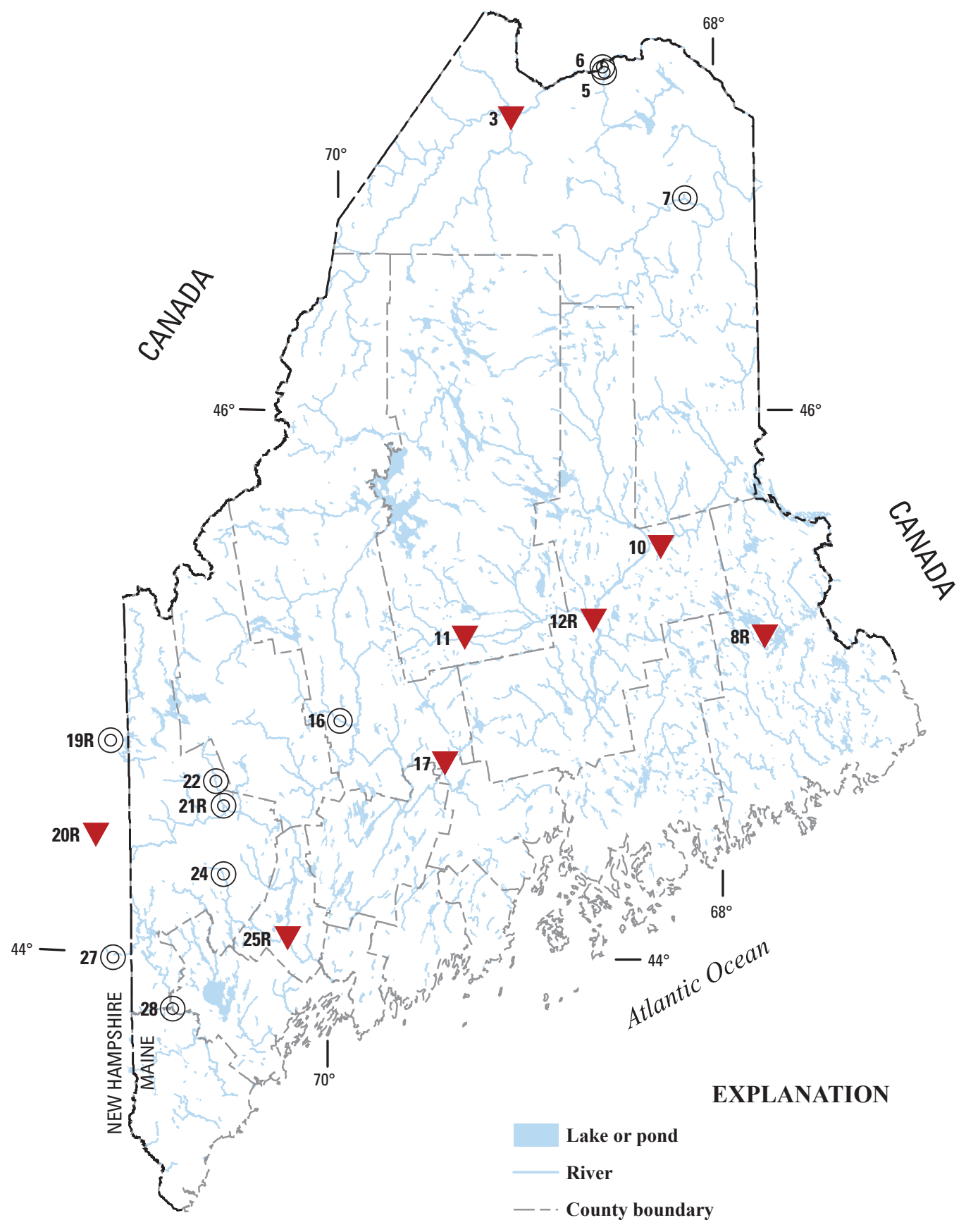

Station and reference number-Symbol indicates how 100-year peak flows based on the period 1937-66 compare to those based on the full record

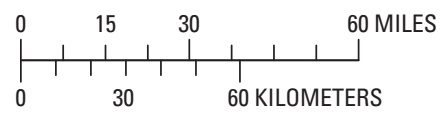

Base from U.S. Geological Survey digital files, Universal Transverse Mercator projection, zone 19
16 (O) Within 90-percent confidence interval of full record

$17 \nabla$ Less than 90-percent confidence interval of full record

" $\mathrm{R}$ " in the reference number indicates station streamflow is regulated

Figure 7. Geographic distribution of 100-year peak flows based on the 1937 to 1966 sub-period that are outside the 90-percent confidence intervals of 100-year peak flows based on full periods. 


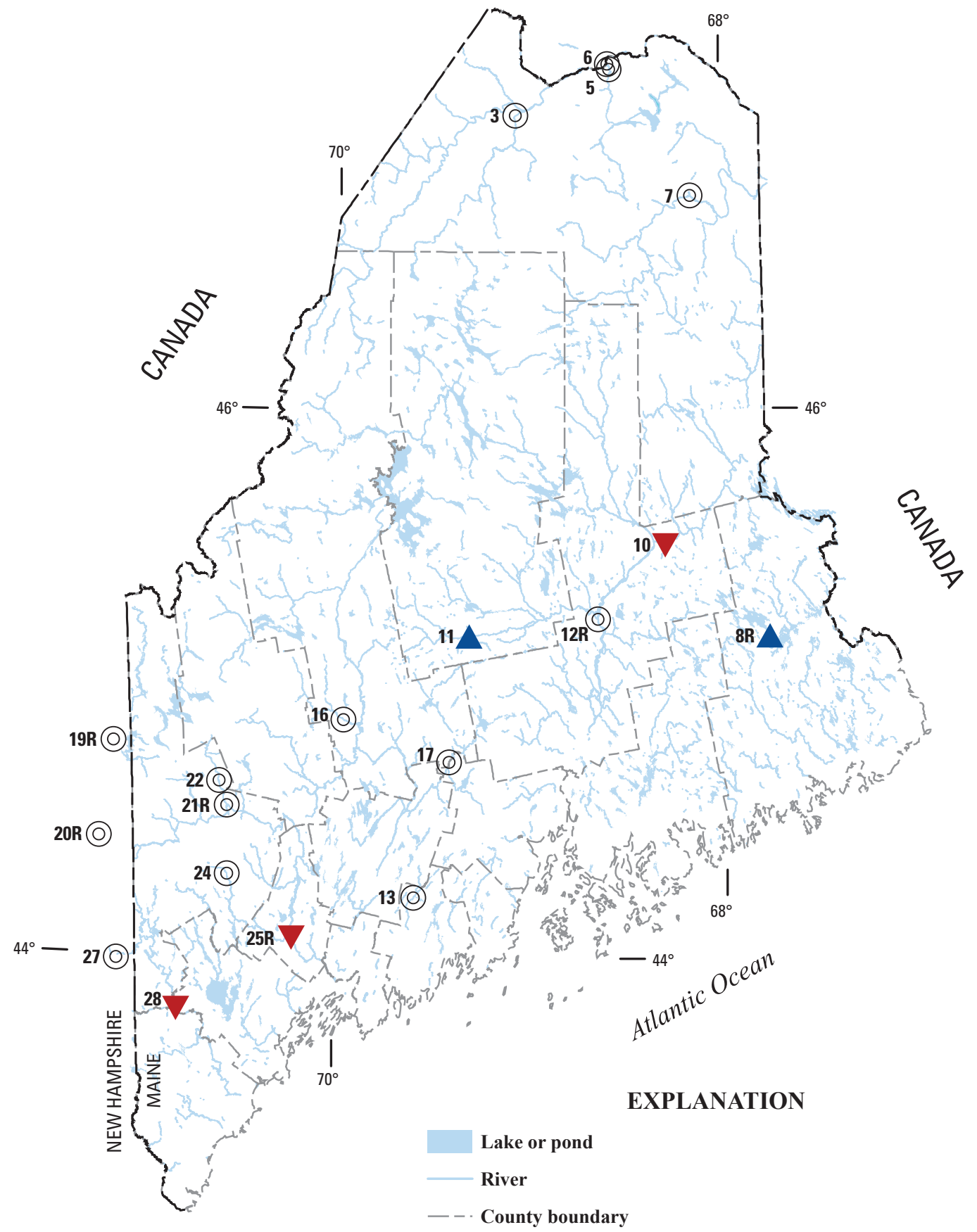

Station and reference number-Symbol indicates how 100-year peak flows based on the period 1970-2006 compare to those based on the full record

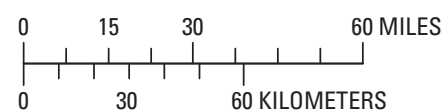

Base from U.S. Geological Survey digital files, Universal Transverse Mercator projection, zone 19
11 Greater than 90-percent confidence interval of full record

3 (O) Within 90-percent confidence interval of full record

10 Less than 90-percent confidence interval of full record

" $\mathrm{R}$ " in the reference number indicates station streamflow is regulated

Figure 8. Geographic distribution of 100-year peak flows based on the 1971 to 2006 sub-period that are outside the 90 -percent confidence intervals of 100 -year peak flows based on full periods. 


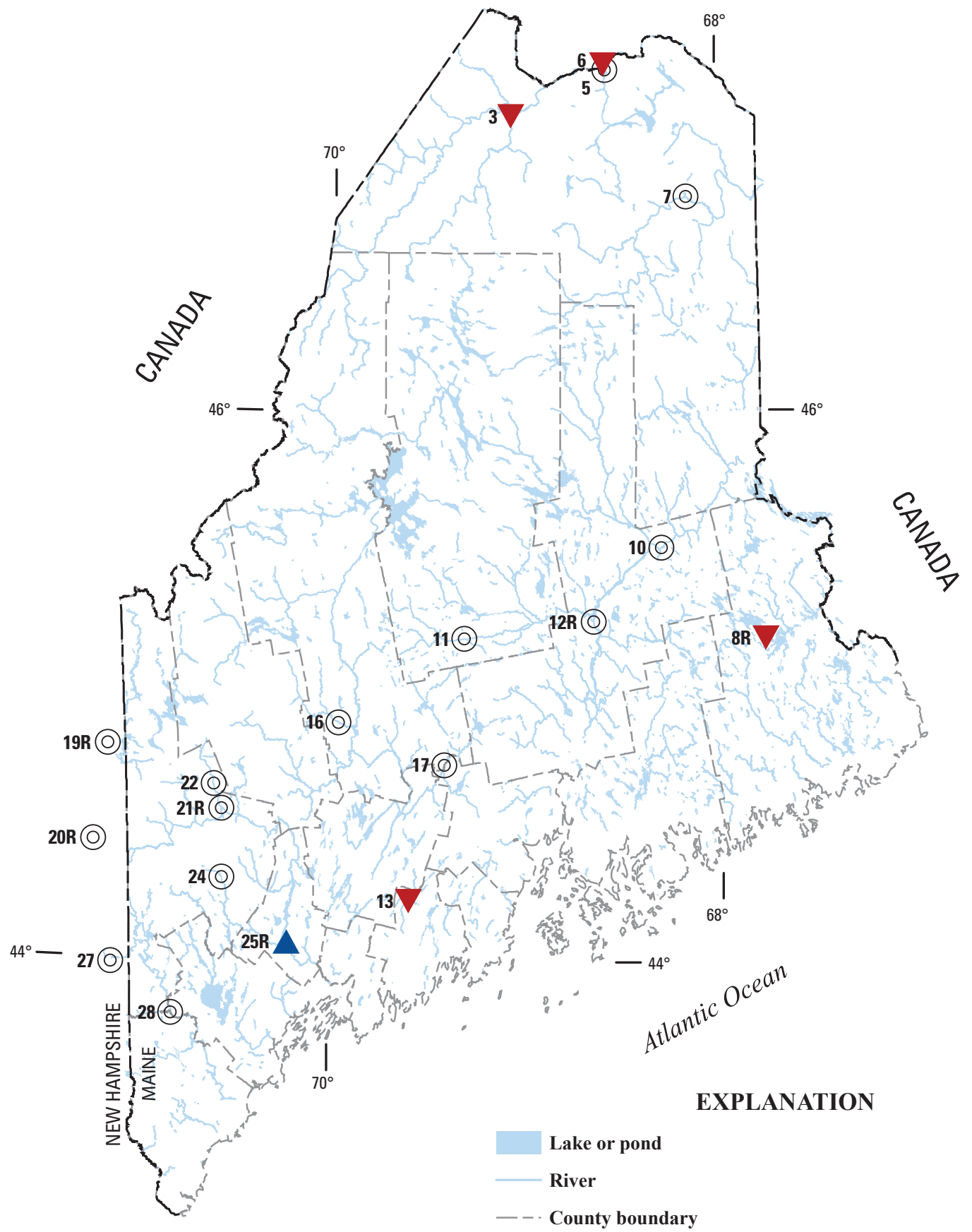

Station and reference number-Symbol indicates how 100-year peak flows based on the period before 1970 compare to those based on the full record

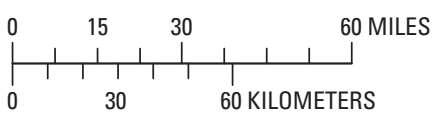

Base from U.S. Geological Survey digital files, Universal Transverse Mercator projection, zone 19
25R Greater than 90-percent confidence interval of full record

17 (O) Within 90-percent confidence interval of full record

13 Less than 90-percent confidence interval of full record

" $\mathrm{R}$ " in the reference number indicates station streamflow is regulated

Figure 9. Geographic distribution of 100-year peak flows based on the start-of-record to 1970 sub-period that are outside the 90 -percent confidence intervals of 100 -year peak flows based on full periods. 


\section{Detailed Results for 5-Year Peak Flows}

For 9 of 28 streamgages, 5 -year peak flows based on the 1977-2006 sub-period were greater than the 90-percent confidence intervals based on full periods, and no streamgages had flows less than the confidence intervals (table 6). Two of the nine streamgages with peaks greater than the confidence interval had a high-outlier peak within the 1977-2006 sub-period. Peak flows with 5-year recurrence intervals based on the 1977-2006 sub-period ranged from 7 percent less to 15 percent greater than flows based on full records at the 20 unregulated streamgages.

For 15 of 28 streamgages, 5-year peak flows based on the 1967-96 sub-period were greater than the 90-percent confidence intervals based on full periods of record, and for 3 streamgages, flows were less than the confidence intervals (table 6). The streamgages with peak flows greater than the confidence intervals are spread throughout the State (fig. 10); all three streamgages with peak flows less than the confidence intervals (streamgages 18, 19, and 20) drain the upper Androscoggin River Basin. One of the three streamgages had a high-outlier peak flow outside of the 1967-96 sub-period. One of 15 streamgages with peaks greater than the confidence interval had a high-outlier peak within the sub-period. One streamgage had a high outlier outside the 1967-96 sub-period but still had a 5-year peak flow greater than the full-period 90-percent confidence interval. Peak flows based on the 1967-1996 sub-period ranged from 6 percent lower to 20 percent higher than flows based on full records at the 20 unregulated streamgages.

For 6 of 28 streamgages, 5 -year peak flows based on the 1957-1986 sub-period were greater than the 90-percent confidence intervals based on full periods of record, and for 4 streamgages, flows were less than the confidence intervals (table 6). For two streamgages (of 22 total), peak flows based on the 1947-1976 sub-period were greater than the confidence intervals, and for six streamgages, flows were less than the confidence intervals.

For 13 streamgages (of 18 total), 5-year peak flows based on the 1937-66 sub-period were less than the full-record 90-percent confidence intervals (table 6); no streamgages had flows greater than the confidence intervals. The 13 streamgages with peak flows less than the confidence intervals are spread throughout the State (fig. 11). Three of the 13 streamgages had high-outlier peak flows outside of the 1937-1966 sub-period. For the limited number of streamgages with records from the 1927-56, 1917-46, and 1907-36 sub-periods, peak flows were both higher and lower than the 90-percent confidence intervals based on full periods of record (table 6).

For 7 of 19 streamgages, 5-year peak flows based on the 1971-2006 sub-period were greater than the 90-percent full-period confidence intervals, and no streamgages had flows less than the confidence intervals (table 7, fig. 12). One of the seven streamgages with peaks greater than the confidence intervals had a high-outlier peak within the 1971-2006 sub-period. Peak flows based on the sub-period ranged from 0.2 percent lower to 15 percent higher than flows based on the full period at the 13 unregulated streamgages. Peak flows for this time period had a consistent signal of higher 5-year peak flows compared to full-period peak flows though not as strong a signal as peak flows based on 1967-1996 flows. For eight streamgages, 5-year peak flows based on flows from the startof-record to 1970 were less than the 90-percent full-period confidence intervals, and no streamgages had flows greater than the confidence intervals (table 7, fig. 13). One of the eight streamgages with peaks less than the confidence interval had a high-outlier peak outside of this sub-period.

\section{Implications for Flood- Frequency Analyses}

The increases in 5-year peak flows based on data from recent decades are consistent with the observed increasing annual peak flows in Maine. The increases in 100-year peak flows based on data from recent decades are generally consistent with observed increasing annual peak flows. In limited cases, 100-year peak flows based on data from recent decades have decreased substantially. Many of these streamgages have high outlier peak flows early in their records; the outliers affected 100 -year peak flows more than they affected long-term changes in annual peak flows. Collins (2009) also found flood-frequency computations to be sensitive to the very high peak flows at some streamgages in New England, as did Lumia and others (2006, fig. 8) in New York.

Annual peak flows have, in general, increased in recent years in Maine as have peak flows with 5- and 100-year recurrence intervals that are based on recent records. Increases in the 5- and 100-year peak flows are, in general, modest when compared to those based on complete periods of record. The highest peak flows are based on the 1967-1996 sub-period rather than the most recent time period. Because large floods in Maine typically result from a combination of snowmelt and rainfall, and in the future may be affected by global warming and by climatic variability (related to sea surface temperature variability or large scale atmospheric patterns), future patterns of change are likely to be complex over both space and time. Peak flows of selected recurrence intervals are sensitive to very high peak flows that may occur once in a century or even less frequently. Therefore, it is difficult to determine whether peak flows for selected recurrence intervals based on recent years of record are more accurate than peak flows of selected recurrence intervals based on the entire historical period (the traditional method). Although peak flows in Maine have, in general, increased during the last 50-100 years, it is difficult to determine whether peak flows are stationary because multi-decadal changes can turn out to be oscillations in longer streamflow records (Koutsoyiannis, 2006; Hamed, 2008). Because peak flows of selected recurrence intervals 


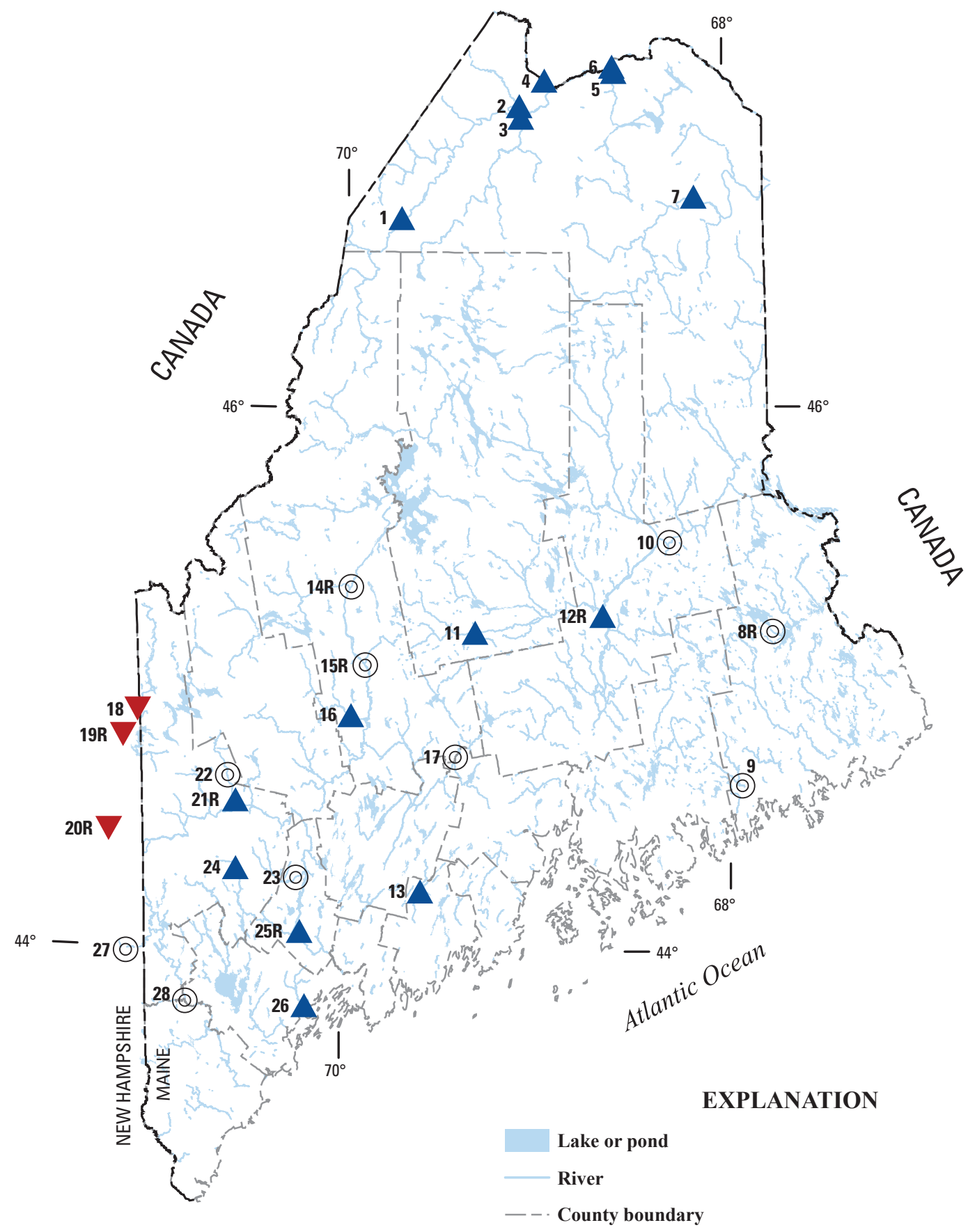

Station and reference number-Symbol indicates how 5-year peak flows based on the period before 1967-96 compare to those based on the full record

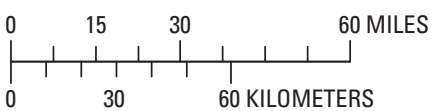

Base from U.S. Geological Survey digital files, Universal Transverse Mercator projection, zone 19
11 Greater than 90-percent confidence interval of full record

22 (O) Within 90-percent confidence interval of full record

18 Less than 90-percent confidence interval of full record

" $\mathrm{R}$ " in the reference number indicates station streamflow is regulated

Figure 10. Geographic distribution of 5-year peak flows based on the 1967 to 1996 sub-period that are outside the 90-percent confidence intervals of 5-year peak flows based on full periods. 


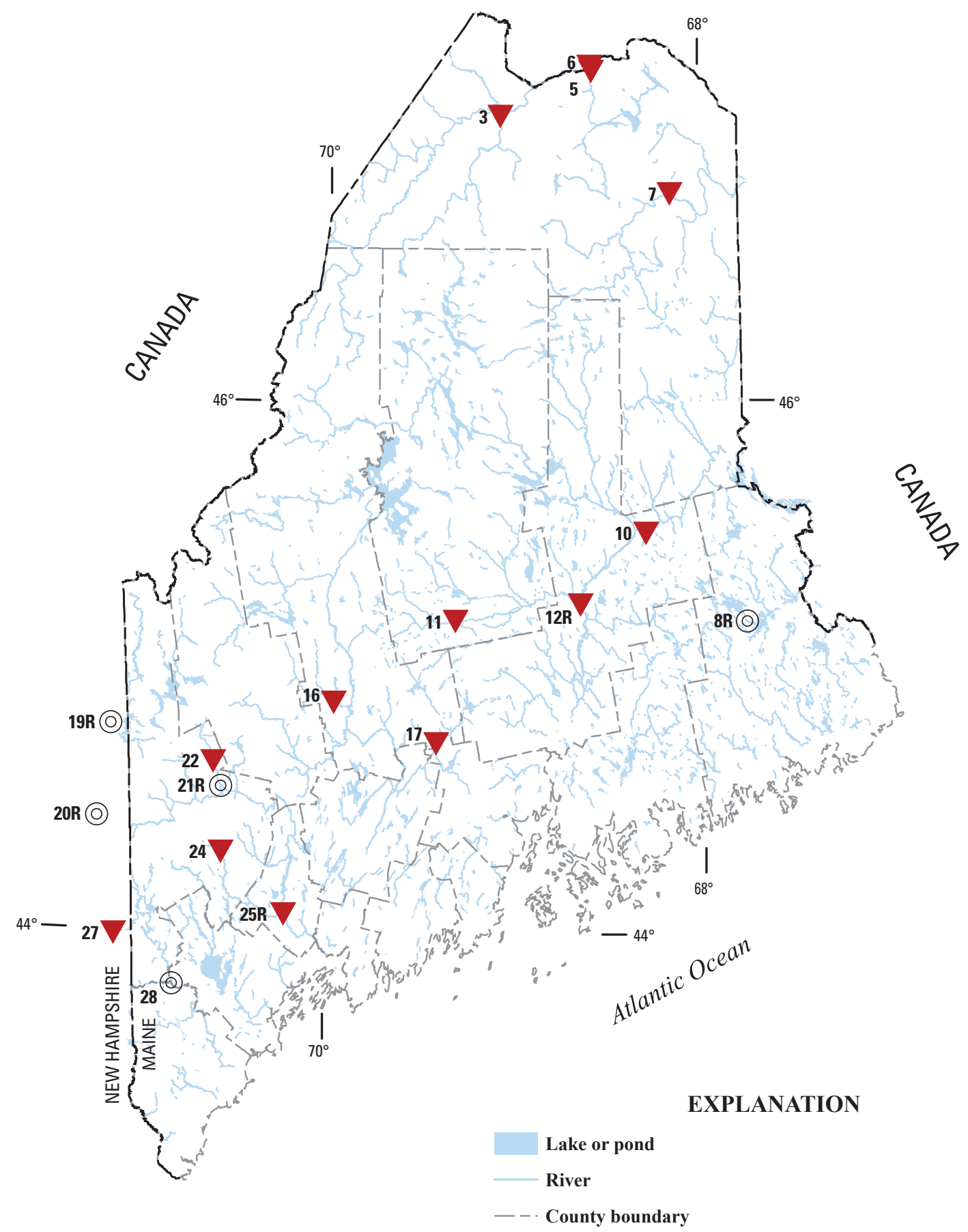

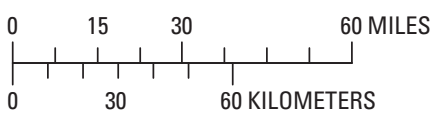

Base from U.S. Geological Survey digital files, Universal Transverse Mercator projection, zone 19
Station and reference number-Symbol indicates how 5-year peak flows based on the period 1937-66 compare to those based on the full record

8R (2) Within 90-percent confidence interval of full record

11 Less than 90-percent confidence interval of full record

" $\mathrm{R}$ " in the reference number indicates station streamflow is regulated

Figure 11. Geographic distribution of 5-year peak flows based on the 1937 to 1966 sub-period that are outside the 90 -percent confidence intervals of 5 -year peak flows based on full periods. 


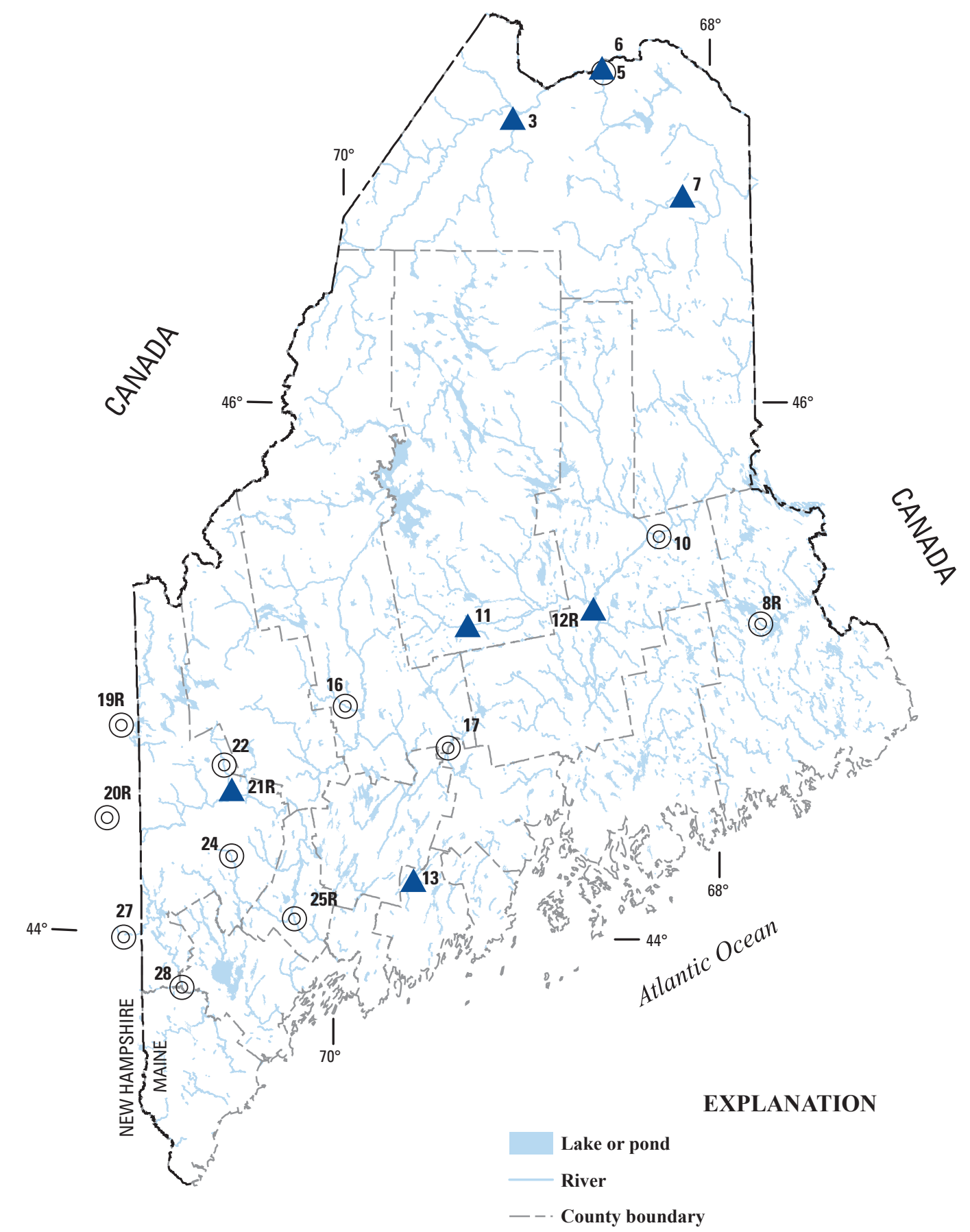

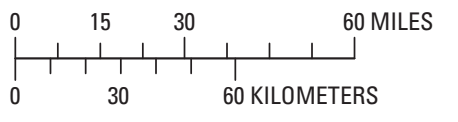

Base from U.S. Geological Survey digital files, Universal Transverse Mercator projection, zone 19
Station and reference number-Symbol indicates how 5-year peak flows based on the period 1970-2006 compare to those based on the full record

3 Greater than 90-percent confidence interval of full record

10 (O) Within 90-percent confidence interval of full record "R" in the reference number indicates station streamflow is regulated

Figure 12. Geographic distribution of 5-year peak flows based on the 1971 to 2006 sub-period that are outside the 90-percent confidence intervals of 5 -year peak flows based on full periods. 


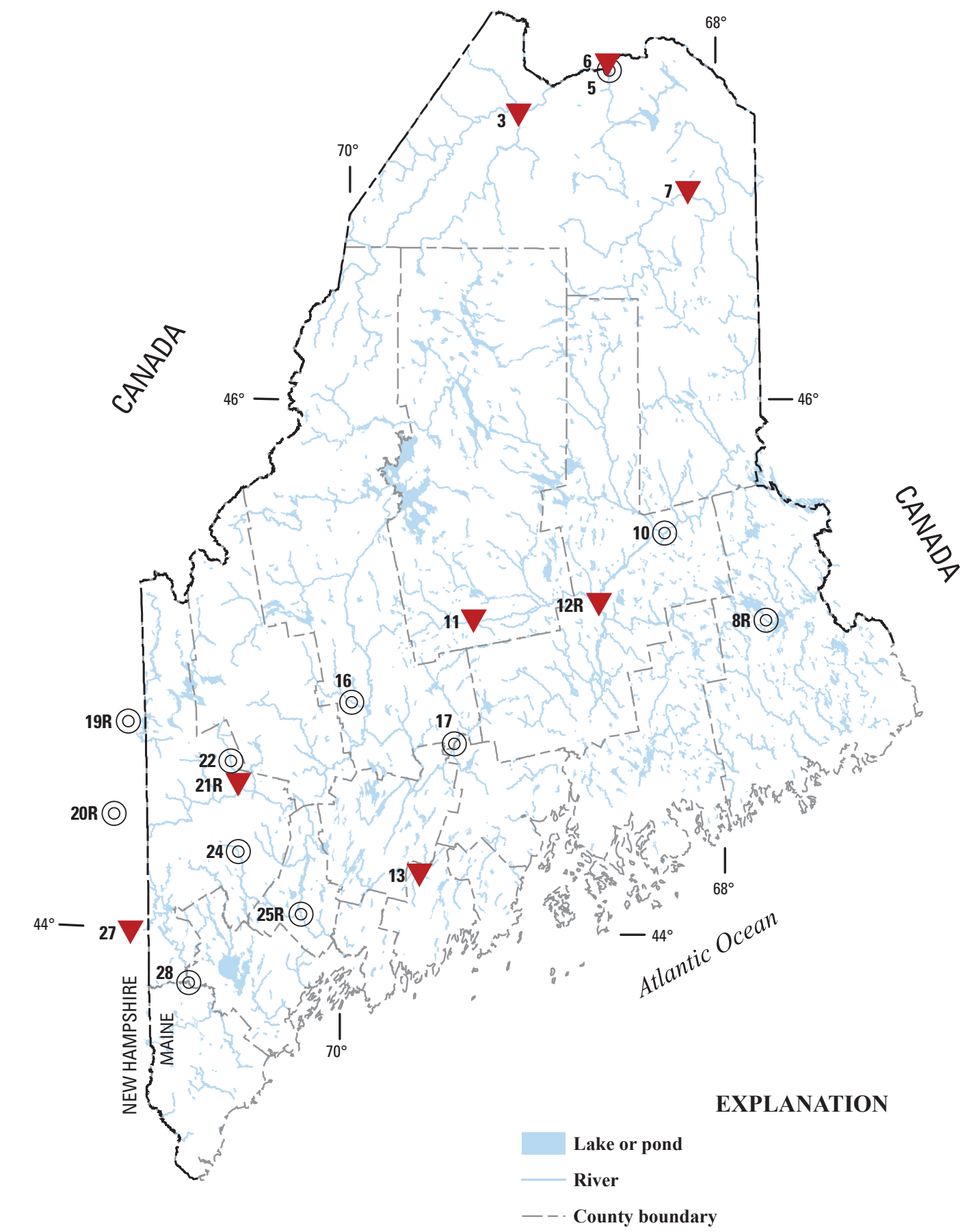

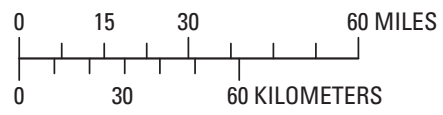

Base from U.S. Geological Survey digital files, Universal Transverse Mercator projection, zone 19
Station and reference number-Symbol indicates how 5-year peak flows based on the period before 1970 compare to those based on the full record

10 (O) Within 90-percent confidence interval of full record

11 Less than 90-percent confidence interval of full record

" $\mathrm{R}$ " in the reference number indicates station streamflow is regulated

Figure 13. Geographic distribution of 5-year peak flows based on the start-of-record to 1970 sub-period that are outside the 90 -percent confidence intervals of 5 -year peak flows based on full periods. 
in Maine may or may not be stationary, one possible conservative approach to computing peak flows of selected recurrence intervals would be to compute these peak flows from both recent annual peak flows and from the entire period of peak flows and then choose the higher computed value (Collins, 2009).

Whether recent or entire periods of record are used to compute peak flows of selected recurrence intervals, the results of this study highlight the importance of using recent data in the computation of the peak flows. The use of only older records could result in the underestimation of peak flows, particularly for peak flows with shorter recurrence intervals such as the 5-year peak flow.

\section{Summary and Conclusions}

For flood-frequency analyses, statistical methods are used to compute peak streamflows for selected recurrence intervals - the average number of years between peak flows that are equal to or greater than a specified peak flow. It is necessary to determine the magnitude of peak streamflows with specified recurrence intervals to safely and economically design bridges, culverts, and other structures that are in, or near, streams. It has long been assumed that the annual peak streamflows used in these computations were stationary over very long periods of time, except in river basins subject to urbanization, regulation, and other direct human activities. Stationarity is the concept that natural systems fluctuate within an envelope of variability that does not change over time. Because of the potential effects of global warming on peak flows, the assumption of peak-flow stationarity has recently been questioned. This study was conducted by the U.S. Geological Survey (USGS), in cooperation with the Maine Department of Transportation (MaineDOT). It will help MaineDOT and others better understand the effects of changing historical peak flows on flood-frequency analyses for streams in Maine. Maine has many streamgages with 50-105 years of recorded annual peak streamflows. In this study, this long-term record has been tested for historical flood-frequency stationarity, to provide some insight into future flood frequency.

Changes over time in annual instantaneous peak streamflows at 28 USGS streamgages with long-term data (50 or more years) and relatively complete records (no more than 5 years of missing data from 1957 through 2006) were investigated in two different ways. Linear trends for the period of record for each streamgage were computed with the Sen slope. Because previous studies have suggested that changes over time may have occurred as a step change around 1970, the step change between each streamgage's older record (startyear to 1970) and newer record (1971 to 2006) was computed using the Hodges-Lehmann estimator.
The median change in peak flows over time for all 28 streamgages (including 8 streamgages with substantial streamflow regulation) was an increase of 15.9 percent based on a linear change and an increase of 12.4 percent based on a step change. The median change for the 20 unregulated streamgages is slightly higher than for all 28 streamgages; it is 18.4 percent based on a linear change and 15.0 percent based on a step change. There were many linear increases of greater than 10 percent, and peak flows at seven streamgages increased by more than 25 percent. In contrast, peak flows at one streamgage decreased by more than 10 percent. Many step changes of greater than 10 percent were noted when comparing older data (1970 and earlier) to newer data (1971 to 2006). Peak flows at three streamgages had step increases of greater than 25 percent, and one streamgage had a decrease of more than 10 percent.

Peak flows for 100- and 5-year recurrence intervals were computed for the 28 streamgages using the entire available annual peak-flow record and multiple sub-periods of that record, using the guidelines (Bulletin 17B) of the Interagency Advisory Committee on Water Data. Magnitudes of 100- and 5 -year peak flows computed from the sub-periods were then compared to those for the full period and to the 90-percent confidence intervals of the peak flows computed from the full period. Sub-periods consisting of 30 years were staggered by 10 years (1907-36, 1917-46, 1927-56, 1937-66, 1947-76, 1957-86, 1967-96, and 1977-2006). Because changes over time in peak flows may have occurred as a step change around 1970, two other sub-periods were analyzed: older data (startof-record to 1970) and newer data (1971 to 2006). The 5-year peak flow is used to represent small and relatively frequent flood flows in Maine, whereas the 100-year peak flow is used to represent large flood flows.

The 1967-1996 sub-period had the highest 100- and 5-year peak flows overall when compared to 100- and 5-year peak flows based on the full period of record; the median difference for all 28 streamgages is 8 percent for both the 100 - and 5-year peak flows. Peak flows with 100 -year recurrence intervals based on the sub-period are from 17 percent lower to 26 percent higher than 100 -year peak flows based on full records at the 20 unregulated streamgages, and peak flows with 5-year recurrence intervals are from 6 percent lower to 20 percent higher than 5-year peak flows based on full records. The 1977-2006 and 1971-2006 sub-periods also showed overall higher peak flows than the full-period peak flows, but these sub-period peak flows are not as high as those based on the 1967-1996 sub-period; the median difference for all streamgages for both sub-periods (1977-2006 and 1971-2006) is 4 percent for 100-year peak flows and 6 percent for 5-year peak flows. The 1937-1966 sub-period showed the lowest 100- and 5-year peak flows overall. The median differences from full-period peak flows are -11 percent for 100 -year peak flows and -8 percent for 5-year peak flows. Overall, differences between the 
sub-periods and the full periods for the 20 unregulated streamgages are similar to differences for all 28 streamgages.

The 1967-96 sub-period had the most streamgages (10 of 28) with 100-year peak flows higher than the 90-percent confidence intervals of the peak flows computed from full periods of record. This sub-period also produced the most streamgages ( 15 of 28 ) with 5-year peak flows higher than the full-period 90-percent confidence intervals. The 1937-66 sub-period had the most streamgages ( 8 of 18) with 100-year peak flows lower than the 90-percent confidence intervals of the full-period peak flows. This sub-period also had the most streamgages (13 of 28) with 5-year peak flows less than the 90-percent confidence intervals. The streamgages with peak flows outside the confidence intervals are spread throughout the State. More streamgages have 5-year peak flows outside the confidence intervals for the 1967-96 and 1937-66 sub-periods than have 100-year peak flows outside the confidence intervals; however, the magnitude of percentage differences between the sub-periods and the full periods are similar for the 5- and 100-year peak flows. This discrepancy is likely due to the lower uncertainty of the 5-year peak flows (narrower 90-percent confidence intervals) compared to the 100-year peak flows.

The increases in 5-year peak flows based on data from recent decades are consistent with the observed increasing annual peak flows in Maine. The increases in 100-year peak flows based on data from recent decades are generally consistent with observed increasing annual peak flows. In limited cases, 100-year peak flows based on data from recent decades have decreased substantially. Many of these streamgages have high outlier peak flows early in their records; the outliers affected 100-year peak flows more than they affected long-term changes in annual peak flows.

Although peak flows in Maine have, in general, increased during the last 50-100 years, it is difficult to determine whether peak flows are stationary because multi-decadal changes can turn out to be oscillations in longer streamflow records. Increases in the 5- and 100-year peak flows based on data from recent decades are, in general, modest when compared to peak flows based on complete periods of record. The highest peak flows are based on the 1967-96 sub-period rather than the most recent sub-period (1977-2006). Peak flows of selected recurrence intervals are sensitive to very high peak flows that may occur once in a century or even less frequently.

Because large floods in Maine typically result from a combination of snowmelt and rainfall, and in the future may be affected by global warming and by climatic variability (related to sea surface temperature variability or large scale atmospheric patterns), future patterns of change are likely to be complex over both space and time. Because peak flows of selected recurrence intervals in Maine may or may not be stationary, it is difficult to determine whether peak flows for selected recurrence intervals based on recent years of record are more accurate than peak flows of selected recurrence intervals based on the entire historical period (the traditional method). One possible conservative approach to computing peak flows of selected recurrence intervals would be to compute these peak flows from both recent annual peak flows and from the entire period of peak flows and then choose the higher computed value.

Whether recent or entire periods of record are used to compute peak flows of selected recurrence intervals, the results of this study highlight the importance of using recent data in the computation of the peak flows. The use of only older records could result in the underestimation of peak flows, particularly for peak flows with shorter recurrence intervals such as the 5-year peak flow.

\section{References Cited}

Benson, M.A., 1960, Characteristics of frequency curves based on a theoretical 1,000-year record, in Dalrymple, T., Flood frequency analysis, manual of hydrology, part 3, flood-flow techniques: U.S. Geological Survey WaterSupply Paper 1543-A, 80 p.

Benson, M.A., 1962, Factors influencing the occurrence of floods in a humid region of diverse terrain: U.S. Geological Survey Water-Supply Paper 1580-B, 64 p.

Cember, R.P., and Wilks, D.S., 1993, Climatological atlas of snowfall and snow depth for the northeastern United States and southeastern Canada: Northeast Regional Climate Center Publication No. RR 93-1, Ithaca, N.Y., 213 p.

Cohn, T.A., and Lins, H.F., 2005, Nature's styleNaturally trendy: Geophysical Research Letters, v. 32, doi:10.1029/2005GL024476.

Collins, M.J., 2009, Evidence for changing flood risk in New England since the late 20th century: Journal of the American Water Resources Association, v. 45, p. 279-290. DOI: $10.1111 /$ j.1752-1688.2008.00277.x.

Dudley, R.W., and Hodgkins, G.A., 2002, Trends in streamflow, river ice, and snowpack for coastal river basins in Maine during the 20th century: U.S. Geological Survey Water-Resources Investigations Report 02-4245, 26 p.

Hamed, H.H., 2008, Trend detection in hydrologic data: The Mann-Kendall trend test under the scaling hypothesis: Journal of Hydrology, v. 349, p. 350-363.

Hayhoe, K., Wake, C.P., Huntington, T.G., Luo, L., Schwartz, M.D., Sheffield, J., Wood, E., Anderson, B., Bradbury, J., DeGaetano, A., Troy, T.J., and Wolfe, D., 2007, Past and future changes in climate and hydrological indicators in the U.S. Northeast: Climate Dynamics, v. 28, p. 381-407. 
Helsel, D.R., and Hirsch, R.M., 1992, Statistical methods in water resources: Elsevier, N.Y., Elsevier, 522 p.

Hodgkins, G.A., 1999, Estimating the magnitude of peak flows for streams in Maine for selected recurrence intervals: U.S. Geological Survey Water-Resources Investigations Report 99-4008, 45 p.

Hodgkins, G.A., and Dudley, R.W., 2005, Changes in the magnitude of annual and monthly streamflows in New England, 1902-2002: U.S. Geological Survey Scientific Investigations Report 2005-5135, 37 p.

Hodgkins, G.A., and Dudley, R.W., 2006, Changes in the timing of winter-spring streamflows in eastern North America, 1913-2002: Geophysical Research Letters, v. 33, L06402, doi:10.1029/2005GL025593.

Hodgkins, G.A., Dudley, R.W., and Huntington, T.G., 2003, Changes in the timing of high river flows in New England over the 20th century: Journal of Hydrology, v. 278, p. $242-250$.

Hodgkins, G.A., Lent, R.M., Dudley, R.W., and Schalk, C.W., 2009, Framework for a U.S. Geological Survey Hydrologic Climate-Response Program in Maine: U.S. Geological Survey Scientific Investigations Report 2009-1115, 24 p.

Hurrell, J.W., Kushnir, Y., Ottersen, G., and Visbeck, M., 2003, An overview of the North Atlantic Oscillation, in The North Atlantic Oscillation-Climatic significance and environmental impact: American Geophysical Union Geophysical Monograph 134.

Interagency Advisory Committee on Water Data, 1982, Guidelines for determining flood flow frequency-Bulletin 17B of the Hydrology Subcommittee: U.S. Geological Survey, Office of Water-Data Coordination, 183 p.

Khaliq, M.N., Ouarda, T.B.M.J., and Gachon, P., 2009, Identification of temporal trends in annual and seasonal low flows occurring in Canadian rivers: The effect of short- and long-term persistence: Journal of Hydrology, v. 369, p. 183-197.
Koutsoyiannis, D., 2006, Nonstationarity versus scaling in hydrology: Journal of Hydrology, v. 324, p. 239-254.

Koutsoyiannis, D., and Montanari, A., 2007, Statistical analysis of hydroclimatic time series: Uncertainty and insights: Water Resources Research, v. 43, doi:10.1029/2006WR005592.

Loiselle, M.C., and Hodgkins, G.A., 2002, Snowpack in Maine-Maximum observed and March 1 mean equivalent water content: U.S. Geological Survey Water-Resources Investigations Report 01-4258, 19 p.

Lumia, R., Freehafer, D.A., and Smith, M.J., 2006, Magnitude and frequency of floods in New York: U.S. Geological Survey Scientific Investigations Report 2006-5112, 152 p.

Milly, P.C.D., Betancourt, J., Falkenmark, M., Hirsch, R.M., Kundzewicz, Z.W., Lettenmaier, D.P., and Stouffer, R.J., 2008, Stationarity is dead: Whither water management?: Science, v. 319, p. 573-574.

National Oceanic and Atmospheric Administration, 2002, Climatography of the United States, no. 81: Monthly station normals of temperature, precipitation, and heating and cooling degree days, 1971-2000, Region 17, Maine, $16 \mathrm{p}$.

New England Regional Assessment Group, 2001, Preparing for a changing climate-The potential consequences of climate variability and change, New England regional overview: Durham, New Hampshire, University of New Hampshire, U.S. Global Change Research Program, 96 p.

Slack, J.R., and Landwehr, J.M., 1992, Hydro-climatic data network (HCDN) - A U.S. Geological Survey streamflow data set for the United States for the study of climate variations, 1874-1988: U.S. Geological Survey Open-File Report 92-129, 193 p. 
Prepared by the Pembroke Publishing Service Center.

For more information concerning this report, contact:

Director

U.S. Geological Survey

Maine Water Science Center

196 Whitten Road

Augusta, ME 04330

dc_me@usgs.gov

or visit our Web site at:

http://me.water.usgs.gov 

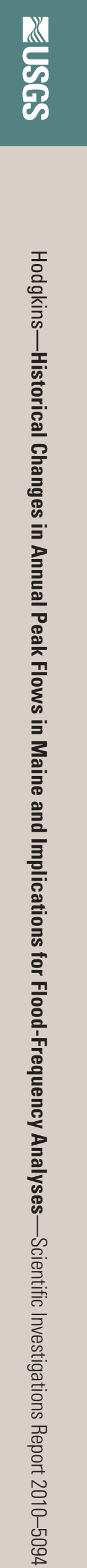